\title{
La caja y general depósito del reino: la concentración comercial en la ciudad de México a fines de la colonia 1770-1790*
}

\author{
Juan Javier Pescador y \\ Gustavo Garza \\ EL COLEGIO DE MÉXICO
}

$\mathrm{E}$ 1 propósito de este artículo es el de analizar la importancia comercial de la ciudad de México en el último tercio del siglo XVII en el marco de la economía colonial, a fin de establecer algunos de los fac-

* Este artículo forma parte del proyecto Dinámica Macroeconómica del Sector Terciario en la ciudad de México, dirigido por Gustavo Garza. Su realización no hubiera sido posible sin la colaboración de Dolores Pulido Navarro. Agradecemos los valiosos comentarios y sugerencias de Juan Carlos Grosso. Igualmente agradecemos a Eutiquio Franco, del Archivo General de la Nación, el habernos permitido trabajar en la galería 6 materiales aún no catalogados sobre las alcabalas de la ciudad de México. tores determinantes de su evolución económica moderna. Se trata, pues, de realizar una caracterización de los distintos circuitos y redes de abasto y comercialización que conectaban a la ciudad con las áreas de producción. Paralelamente se enuncian algunas hipótesis para explicar la naturaleza de la concentración de actividades comerciales, no únicamente en los conocidos términos de monopolio económico y centralismo político, sino incorporando los aspectos locacionales financieros y de transporte que prevalecían en la época, así como también elementos de la composición 
económica interna de la capital del virreinato.

La información utilizada se obtuvo de los registros de las alcabalas de la ciudad, donde quedaban detalladamente asentados la gran mayoría de los productos introducidos a la capital provenientes, lo mismo del interior del reino que de Europa, Filipinas, el Caribe y Sudamérica. Se utilizaron igualmente las estadísticas económicas sobre la ciudad generadas por la Real Aduana de México. Los libros de la Real Aduana de México registraban todas las mercancias introducidas a la capital de acuerdo al ramo al que pertenecían, el arriero que las conducía, el valor en factura del producto, la alcabala que pagaba, la fecha en que era introducida y la persona a cuyo nombre estaba extendida la factura.

\section{TRANSPORTE Y MERCADO COLONIAL}

En el siglo XviII la infraestructura carretera del país fue uno de los principales obstáculos para el florecimiento del tráfico comercial. La falta de caminos y el deficiente estado en que se encontraban las rutas existentes no pasó desapercibida para funcionarios y viajeros, quienes vieron en ella una sólida barrera que impedía y retardaba . el comercio colonial. ${ }^{1}$

Dado el pésimo estado de las carreteras novohispanas, la adaptación y uso de la carreta en México terminó por fracasar, al grado de que en

1 Rees, Transportes, 1976, p. 73. el siglo xviI no era el principal medio de transporte. ${ }^{2}$

Los arrieros tardaban seis semanas en recorrer el camino entre México y Guadalajara o entre Zacatecas y México.

Valladolid estaba a dos semanas y media de la capital. Para ir de Mérico a Veracruz o a Córdoba eran tres semanas.

Durango, Sombrerete y Nombre de Dios tomaban entre siete y ocho semanas de camino. No antes de nueve semanas de camino era posible llegar a Monterrey o a Parral. ${ }^{3}$ Según estimaciones recientes, la capacidad de carga de una mula era de 10 arrobas, esto es poco más de 110 kilos. ${ }^{4}$

De esta suerte, la transportación de mercancías y personas sólo era posible con altos costos y era una empresa sumamente riesgosa.

El transporte de pasajeros era prácticamente inaccesible para el grueso de la población. Viajar en 1784 de México a Guadalajara costaba 200 pesos; $^{5}$ el costo por ejemplo de transportar azúcar de Tuxtla en Veracruz a la ciudad de México representaba cerca del $60 \%$ del valor del azúcar misma. ${ }^{6}$

El traslado de carga en trenes de mulas tenía fuertes gravámenes que elevaban los costos del transporte. Los impuestos fiscales, como alcabalas, fletes y peajes constituían una de las más poderosas trabas para el florecimiento

2 Ringrose, Carting, 1970, pp. 34 y ss.

3 Bahena, Transportación, 1985, apéndice.

4 Hassig, Trade, 1985, p. 193.

5 Ortiz Hernán, Caminos, 1970, p. 161.

6 Van Young, "Siglo", 1988, p. 230. 


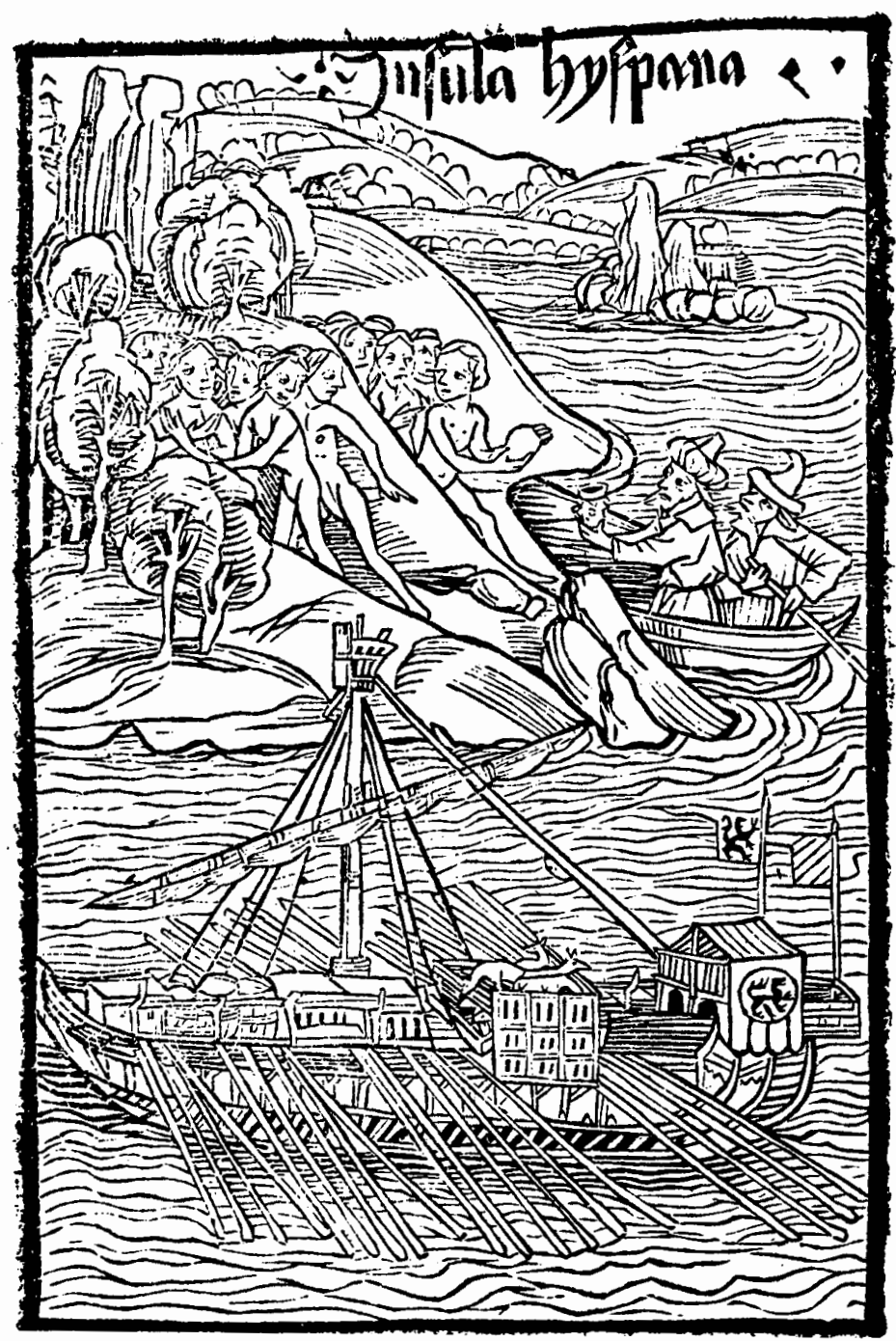


de la circulación de mercancías. ${ }^{7}$ El gobierno virreinal, además, nunca reinvirtió en la red de caminos los ingresos fiscales que ahí colectaba, por lo que los aranceles se convirtieron en una vía para transferir recursos del comercio a otros sectores. ${ }^{8}$

Relegada la tarea de la construcción de caminos a la voluntad de particulares, la red carretera colonial aumentó a un ritmo lento y penoso, detenido frecuentemente por disputas entre los grupos comerciales de distintas ciudades, y subordinado a los criterios de inercia y competencia, en los que se duplicaban funciones, se aumentaban costos de construcción y se organizaba ineficientemente la ejecución de las obras. ${ }^{9}$

Por otra parte, los caminos estaban llenos de bandoleros y salteadores, quienes frecuentemente desvalijaban las caravanas comerciales, lo que obligaba a los mercaderes a pagar sus propias escoltas y, con ello, a aumentar el precio de los productos en el mercado terminal. ${ }^{10}$

En época de lluvias el tránsito se tornaba aún más difícil, lo mismo en las zonas calientes que en la altiplanicie mexicana. En esta última, durante la época pluvial, la crecida de ríos y arroyos frecuentemente interrumpía la comunicación al llevarse las aguas broncas los puentes y vados de los ca-

7 Bahena, Transportacion, 1985, pp. 132 y ss.; Hassig, Trade, 1985, p. 215.

8 Rees, Transportes, 1976, p. 73.

9 Rees, Route, 1971 , pp. 166 y ss. explica estos dos criterios que prevalecieron en la construcción de los caminos entre México y Veracruz.

10 Bahena, Transportación, 1985, pp. 186 y ss. minos, dejando varadas las recuas por algún tiempo.

Los costos del flete de carga en carretera dependían de la duración del viaje, la estación del año y las condiciones del camino. El viaje entre México y Veracruz podía tomar hasta dos semanas adicionales, según se combinaran estos factores. ${ }^{11}$

El transporte de las mercancias importadas que llegaban a Veracruz presentaba otra dificultad:

[...] La salida de las fotas estaba condicionada por la posición del núcleo de alta presión subtropical del Atlántico y los vientos que to circundaban. El propósito consistía en utilizar los vientos del noroeste en su posición al norte durante el verano, en el viaje de ida, $y$ aprovechar las ventajas del cinturón de vientos del oeste en el viaje de regreso. Pero aunque el sistema de circulación de los vientos favorecía el sistema de navegación, obstaculizaba la transportación terrestre en la Nueva España, ya que los galeones invariablemente arribaban al principio o en los primeros meses de la estación de lluvia, cuando los caminos y veredas que unían al puerto con la capital, con mucha facilidad se veían reducidos a auténticos lodazales $[\ldots]^{12}$

De esta suerte, el grueso de la carga introducida en Veracruz era generalmente transportada al interior del reino en la temporada de lluvias, elevando los costos del flete y agregando gastos adicionales de mantenimiento de arrieros y bestias. ${ }^{13}$

\footnotetext{
11 Rees, Transportes, 1976 , p. 86.

12 Ibid., p. 41.

13 Ibid., p. 88.
} 
Bajo estas condiciones, el transporte de carga requería de fuertes y arriesgadas inversiones para su realización. Sólo grandes inversionistas con suficiente capital y crédito podian financiar la transportación de mercancías en tales condiciones, y sólo podían ser transportadas mercancías cuyo valor por unidad fuese lo suficientemente alto para volver absorbible y rentable el costo de traslado. ${ }^{1 / 4}$

Sin ríos navegables y sin una infraestructura carretera adecuada, el comercio en el siglo XviI estuvo condenado a realizarse a lomo de mula, a elevados costos, bajo fuertes riesgos y sin permitir la completa constitución de un mercado nacional, para asombro de los viajeros. ${ }^{15}$

Estudios recientes sobre la historia económica colonial han puesto en evidencia varias características del funcionamiento económico del país en la segunda mitad del siglo XviI.

La economía de la Nueva España experimentó un crecimiento

[...] desigual y segmentado, con una fuerte tendencia hacia la regionalización lindante con la autarquía económica, y concomitante con un mercado "nacional" débil $[\ldots]^{16}$

El atraso técnico en el sector agricola, aunado a la incapacidad de los

14 Van Young, "Siglo", 1988, p. 221.

15 Ward, México, 1981, pp. 36-37, se sorprendía en 1827 de las condiciones de transporte en Mexico, donde aun el suministro de cereales a los centros urbanos era caro e incierto. Ward concluía que para el grueso de la producción del país no había un mercado nacional.

16 Van Young, "Siglo", 1988, p. 208. agentes económicos de consolidar y desarrollar el débil mercado nacional dadas las serias limitaciones del transporte, canceló toda vía de expansión productiva.

Sin las posibilidades de las economías de escala vinculadas a la significativa expansión de mercados tanto espacial como económicamente, las actividades productivas pudieron haber permanecido a un nivel relativamente bajo de diferenciación con divisiones de clase concomitantemente bajas y regionalización consecuentemente fuerte. ${ }^{17}$

Las actividades económicas novohispanas padecían el enorme peso del sistema fiscal colonial:

[...] Los cargos y restricciones impuestos a casi toda forma de actividad económica, aumentaban los costos de las empresas, suprimían la iniciativa, distorsionaban los mercados de factores, elevaban los costos de transacción y reducían la productividad de la economía en general $[\ldots]$ Su efecto consistió no sólo en reducir la producción de las empresas que lograron sobrevivir y hasta florecer; el impacto más importante de este sistema consistió en impedir el desarrollo de las actividades nuevas y más productivas. El Estado mismo no desempeñó muchas funciones que habrian podido aumentar la productividad (mejorar los transportes, invertir en capital humano $[\ldots])^{18}$

17 Ibid, p. 214.

18 Coatsworth, Origenes, 1990 , p. 47. 
La economía mexicana no se vio beneficiada por ninguno de los efectos positivos que la centralización estatal tuvo en Europa occidental, pues el país no aventajó en servicios públicos, sistema carretero o facilidades portuarias. ${ }^{19}$

El último tercio del siglo XviI representó para la Nueva España un periodo de desaceleración del crecimiento económico y demográfico, acompañado de una pauperización de los niveles de vida de gran parte de la población, ${ }^{20}$ un nulo avance tecnológico en la productividad agrícola, $y$ un notable incremento inflacionario en los precios de los artículos de subsistencia. ${ }^{21}$

Los altos costos de transporte indudablemente jugaron un papel preponderante en la inhibición del crecimiento del mercado; ${ }^{22}$ el transporte de granos, por ejemplo, era tan lento y caro que impedía la existencia de una correlación estable entre los precios del maíz en lugares cercanos entre sí como el Bajío y la ciudad de México: 23 llevar a lomo de mula una fanega de maíz 20 kilómetros costaba un real, por lo que rara vez los hacendados y rancheros podían soportar los costos de enviar sus granos a mercados situados a más de una semana de distancia. ${ }^{24}$

19 Ibid., p. 55.

20 Van Young, "Siglo", 1988, p. 210; Ouweneel y Blijleveld, "Economic", 1989, p. 508.

21 Garner, "Price", 1985, p. 324.

22 Van Young, "Siglo", 1988, p. 215.

23 Ouweneel y Blijleveld, "Economic", 1989, p. 487 .

24 En 1826 transportar una fanega de maíz de León a Guanajuato costaba 2.5 reales, en tanto que el precio de este producto en los mismos
La débil integración del mercado nacional generó varias de las características de la economía colonial, entre las que destacan la existencia de mercados regionales aislados, de extensiones geográficas más bien limitadas, con una muy tenue exportación de productos agrícolas a otras regiones y, sobre todo, la primacía de un bajo nivel general de intercambio comercial entre las distintas áreas del reino. ${ }^{25}$

Un proceso de aislamiento semejante debido a la ineficiente red carretera, se daba en otros países de América Latina, como es el caso de Brasil. ${ }^{26}$

En esa débil red comercial, las ciudades novohispanas se llevaron la palma al mostrar un tráfico mercantil marcado por el efecto de iceberg, según el cual:

[...] solamente la punta de la economía regional fue arrastrada a conexiones comerciales más amplias, mientras que la enorme masa de ella era totalmente producida, consumida y negociada en un nivel intrarregional solamente $[\ldots]^{27}$

La concentración de casi el total de las actividades comerciales en cuatro o cinco zonas urbanas, obedeció principalmente a la endeble integración económica del país, cuyo

sitios oscilaba entre ocho y doce reales la fanega. Brading, "Comments", 1989, p. 532. 25 Van Young, "Siglo", 1988, p. 219; Hassig, Trade, 1985 , p. 267.

${ }^{26}$ Kuznesof, "Role", 1980, pp. 571 y ss.

27 Van Young, "Siglo", 1988, p. 219. 
[...] mercado "nacional" estaba profundamente desarticulado y en el cual ambos mercados, el nacional y el regional, eran débiles y porosos, esto es, en ambos hubieron relativamente pocos compradores y vendedores y en ambos muchos productos nunca llegaron siquiera a comercializarse. ${ }^{28}$

El tráfico novohispano mercantil se concretaba a mercancías suntuarias que pudiesen absorber los fletes de transporte, ${ }^{29}$ por lo que ha sido com. parado mas bien con una caravana transahariana ${ }^{30}$ que, a pesar de transportar bienes de alto valor unitario, no tenía ninguna repercusión en la integración económica de las regiones por las que transitaba. Aunque ciertamente hubo una circulación considerable a nivel nacional de productos no sunturarios, tales como herramientas, textiles, hierro, cera y cacao, es indudable que predominaba la débil inte. gración económica y el aislamiento a nivel regional. ${ }^{31}$

28 Ibid., p. 221.

29 Ouweneel y Blijleveld, "Economic", 1989, p. 489 .

30 lbid.

3i Brading, "Comments", 1989, p. 532, en una crítica a la metáfora de la caravana transahariana apunta la respetable circulación de productos no suntuarios que existía entre Michoacán, Jalisco, y el Bajío, lo mismo que la existencia de textiles poblanos en Saltillo o bien rebaños de Coahuila en la ciudad de Mexico. Coatsworth, "Comments", 1989, p. 538, también trata de matizar la caracterización del comercio colonial interno señalando que existía una serie de productos domésticos que sí circulaban en un tráfico de larga distancia y que, si bien no tenía el mismo grado de integración que los mercados europeos, indudablemente funcionaba para ciertos productos y manufacturas.

\section{DISTRIBUCIÓN COMERCIAL EN EL} SISTEMA DE CIUDADES NOVOHISPANAS

Es particularmente arriesgado tratar de establecer el nivel de concentración de las actividades comerciales del virreinato, en la ciudad de México, partiendo de las opiniones y estimaciones de las obras e informes de la época, muchos de ellos interesados e inexactos, dadas las fuertes controversias que en la segunda mitad del siglo XVII entablaron funcionarios, comerciantes de la capital y comerciantes de los principales centros urbanos de provincia.

Los más de estos informes, sumamente interesados en preservar o bien en contrarrestrar el poder económico y la influencia política del Consulado de México, ofrecen visiones sesgadas y sumamente dificiles de equiparar. Una forma más confiable consistiría en incorporar las investigaciones recientes sobre las alcabalas de Nueva España, así como los informes de la Real Hacienda al respecto. Lamentablemente, las magníficas series elaboradas por Juan Carlos Garavaglia y Juan Carlos Grosso, no incluyen a Veracruz ni a la ciudad de México, lo que obligaria a tomar los riesgos y sesgos inherentes a toda seric de datos cruzados, sin poder garantizar a la postre una comparación confiable.

Fue por ello que se decidió utilizar solamente una serie de la Dirección General de Alcabalas, que incluía a Veracruz y a la ciudad de México, junto con el resto de las receptorías para el año completo de 1778 , que si bien no ofrece una visión dinámica en el tiempo por tratarse de un solo año, nos puede proporcionar un acerca- 


\section{SECUENCIG}

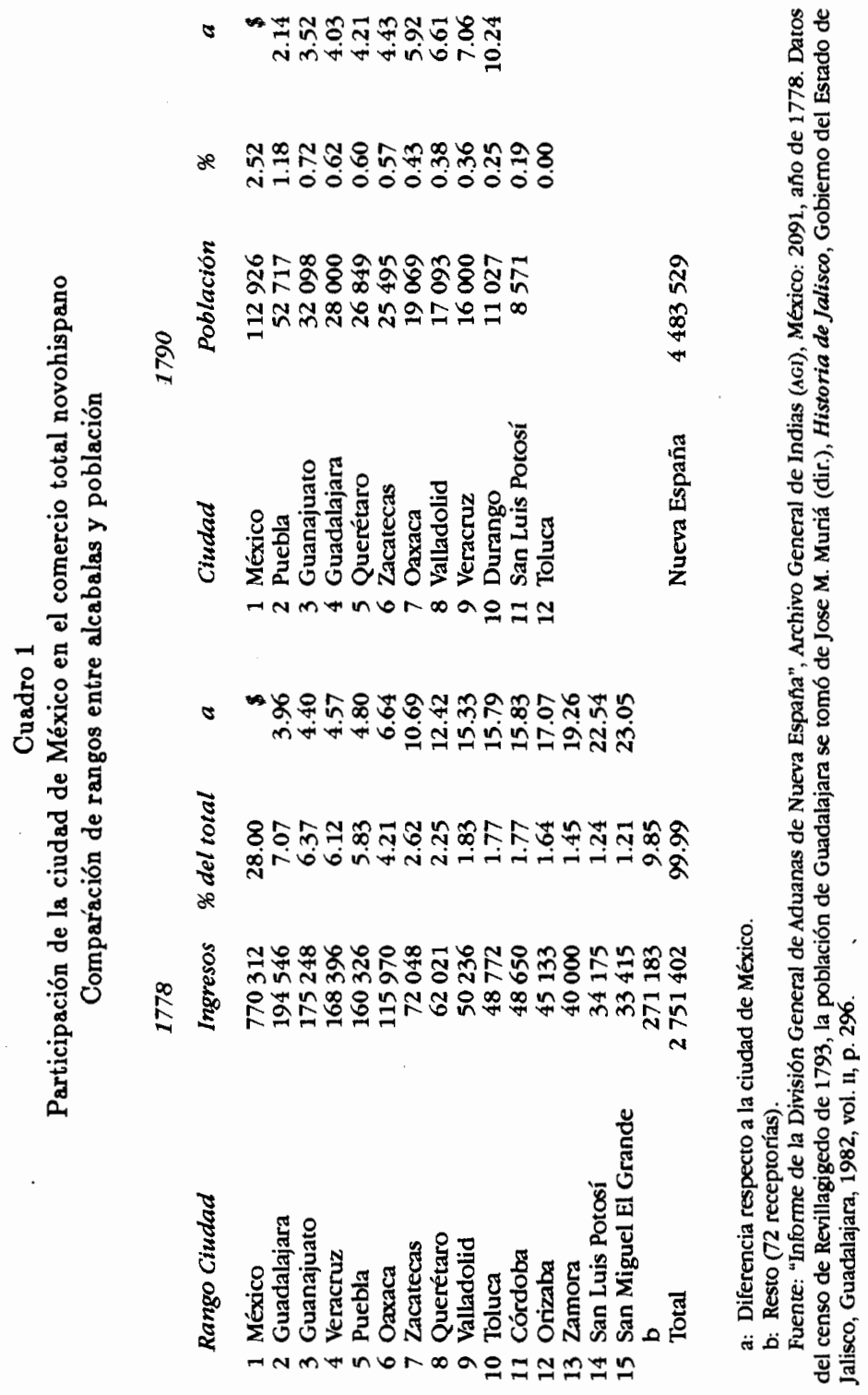


miento a la distribución relativa del movimiento comercial de los distintos suelos alcabalatorios.

Con base en la lista completa de la Dirección General de Alcabalas, podemos observar (cuadro 1) que la ciudad de México aportaba, en 1778 , el $28 \%$ del volumen total de ingresos por alcabala, lo que refleja un nivel bastante alto de concentración del comercio, máxime si se toma en cuenta que la población de la ciudad apenas representaba el $2.5 \%$ de la población total de Nueva España (cuadro 1).

Le seguían a la capital, en importancia comercial, las ciudades de Guadalajara, con el $7 \%$ de concentración; Guanajuato, con 6.4\%; Veracruz, con 6.1\%; Puebla, con 5.8\%; Oaxaca, con 4.2\%; Zacatecas, con 2.6\%; Querétaro, con $2.2 \%$ y, finalmente, Valladolid, Toluca y Córdoba, con porcentajes entre 1.7 y 1.8 por ciento.

De modo que se pudiera obtener una perspectiva confiable del tráfico comercial en Nueva España, nos pareció acertado comparar el nivel de ingresos por concepto de alcabalas en las primeras quince ciudades del reino, con su nivel de población según los recuentos oficiales de fines del siglo XVIII. Su importancia comercial no se correspondía con su densidad poblacional.

Como se señaló arriba México, si bien era la localidad más grande del reino, no contenía ni al $3 \%$ del total de habitantes; Puebla, por su parte, era la segunda ciudad más grande con más de 50000 habitantes $y$, sin embargo, su rango económico y comercial era quinto; en el extremo opuesto estaba Guadalajara, segunda en importancia económica, y cuarta en el orden demográfico. La privilegiada ubicación de Guadalajara le brindaba una situación ventajosa en el comercio occidental y noroccidental del país; ${ }^{32}$ Guanajuato, Zacatecas, Oaxaca, Toluca y Valladolid mantenían prácticamente las mismas posiciones en comercio y población.

Un caso particular es Veracruz, cuyo volumen de población no era alto y no obstante, por su situación privilegiada en el comercio ultramarino del Atlántico, ocupaba el cuarto sitio en importancia comercial.

El caso opuesto es Durango, ubicada entre las primeras diez ciudades más grandes y con un pobre $22^{\circ}$ lugar como receptoría alcabalatoria.

Un segundo grupo de receptorías intermedias estaba formado por Toluca, Córdoba, Orizaba, San Luis Potosí, Zamora, San Miguel el Grande, León, Cuernavaca, Chihuahua y Durango, con aportaciones entre 1 y $2 \%$ total. El resto, más de 80 receptorías, aportaban menos del 1 por ciento.

En las postrimerías del virreinato, por tanto, existía una elevada concentración urbana de las actividades mercantiles, siendo que las primeras diez ciudades, esto es el 5\% de la población de Nueva España, acaparaba dos terceras partes del comercio total. La ciudad de México se constituía con mucho en el principal punto de concentración, absorbiendo un volumen de comercio prácticamente equivalente a la del existente en Guadalajara, Guana-

32 Van Young, "Conflict", 1984, pp. 62-63. 
juato, Veracruz, Puebla, Zacatecas, Oaxaca, Valladolid y Toluca.

Si observamos el cuadro 1 , vemos que de ninguna manera había correspondencia entre la concentración comercial y la concentración demográfica. La ciudad de México tenía más de una cuarta parte del comercio del reino y menos del $2.5 \%$ de la población total.

Lo mismo sucedía, toda proporción guardada, con Guadalajara y Veracruz. La primera tenía el $7 \%$ del comercio y el $1 \%$ de la población, en tanto que la segunda absorbía el $6 \%$ del comercio y el $\mathbf{0 . 3 \%}$ de la población. Puebla tenía un rango inferior en comercio al que le correspondía en población, ya que era la segunda ciudad más grande y sólo la quinta con más tráfico mercantil. Oaxaca, Querétaro, Valladolid y Zacatecas observaban niveles demográficos muy semejantes a sus rangos comerciales.

Ninguna de las principales ciudades tenía un rango demográfico a la altura de su participación porcentual en el comercio total, lo que evidenciaba su carácter de centros mercantiles de ciertas áreas del reducido mercado interno colonial. El caso extremo era sin duda el de la ciudad de México, que desde las postrimerías del siglo xvII fungía como centro comercial de primer orden en el vasto y desintegrado territorio de la Nueva España.

\section{DistRIBUCIÓN EN LOS CAMINOS REALES}

La distribución espacial de las alcabalas, según las rutas terrestres en que estaban situadas las receptorías, permite detectar las tendencias de los flu- jos comerciales a lo largo de las rutas terrestres existentes (véase mapa 1).

Los suelos alcabalatorios del eje Acapulco-México, esto es Cuernavaca, Taxco, Cuautla y Acapulco, representan apenas $4 \%$ del volumen total; ordenadas por su rango a nivel nacional, Cuernavaca es la receptoría 18, Taxco, la 31, Cuautla, la 33 y Acapulco, la 70. La ruta hacia Pachuca y Zimapán (incluidos Ixmiquilpan, Huichapan, Ápam, Tulancingo, Valles y Tampico) representa también el 4\%. A excepción de Pachuca (la receptoría número 30 ) ninguna de las doce receptorías de este camino está entre las primeras 40 del país, y sólo Zimapán y Valles están ubicadas entre las primeras 60.

De escasa representación resulta igualmente el camino real MéxicoOaxaca-San Cristóbal y todas las receptorías adyacentes (Chilapa, Ixtlahuaca, Teposcolula, Tehuantepec, etcétera), pues una ruta de 287 leguas sólo representa $7 \%$ del total de alcabalas. lin este eje, el centro es Oaxaca, la sexta receptoría más importante del reino, que concentra casi el $50 \%$ de las alcabalas de dicho camino.

Mucho más importante es el camino México-Toluca-Zitácuaro-Valladolid-Sayula, corredor de apenas 69 leguas de distancia que concentra $16 \%$ del total nacional. De sus receptorías, Valladolid y Toluca están entre las primeras diez; Zamora, entre las primeras veinte; Pátzcuaro, entre las primeras 30; asi el corredor Toluca-Valladolid es uno de los ejes principales de la circulación de mercancías, y la distribución interna que presentan sus receptorías no está concentrada en una sola ciudad. 


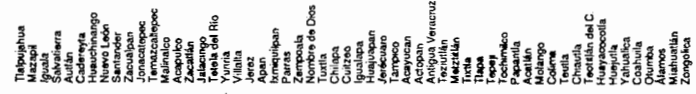

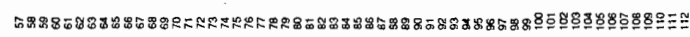

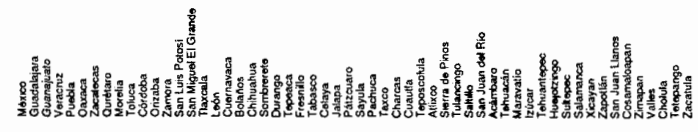

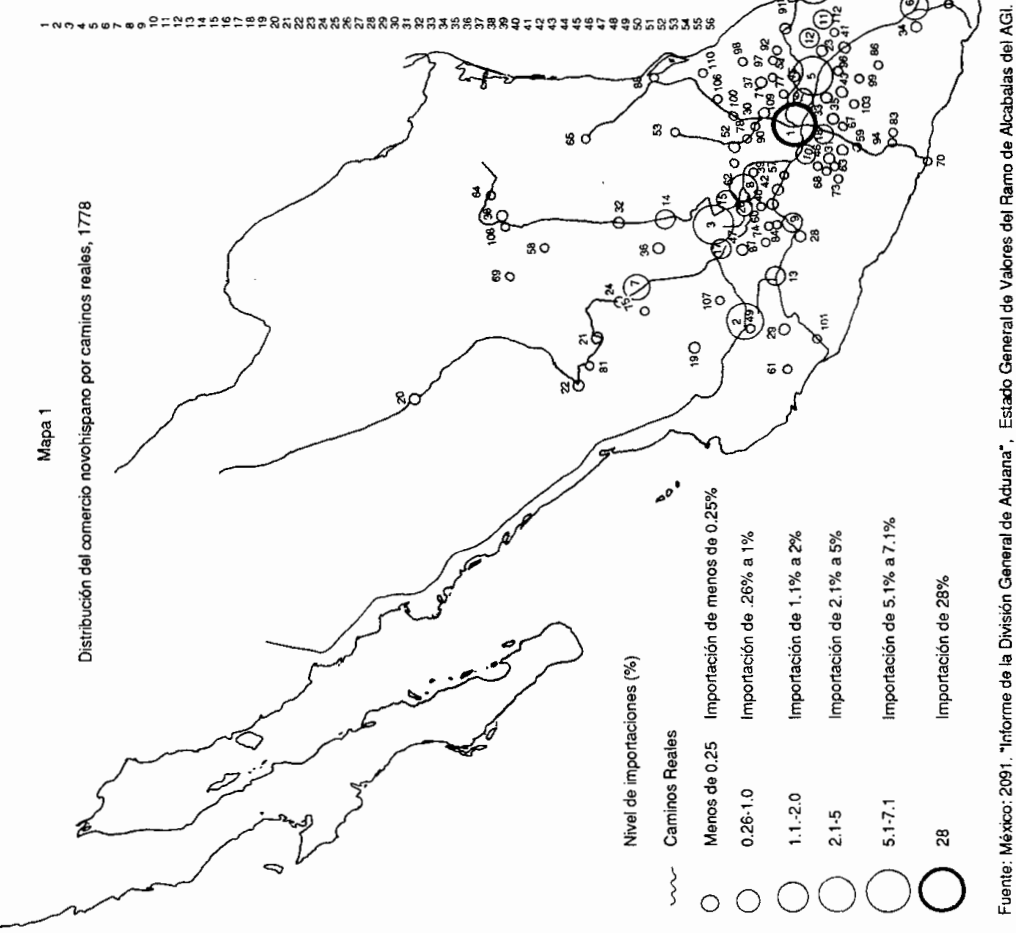


El camino México-Guadalajara es aún más importante, pues concentra una cuarta parte del total del reino, si bien su capacidad de importación de mercancías no presenta una distribución tan homogénea como la de la ruta México-Valladolid; este corredor alberga tres de las primeras cinco ciudades más importantes económicamente del reino (México, Guadalajara, Guanajuato, los tres primeros lugares, en ese orden). Si se considerara el camino Toluca-Valladolid como ramal de la ruta México-Guadalajara ambos espacios concentrarían el $40 \%$ del volumen nacional.

La ruta México-Zacatecas, por su parte, agrupa el $11 \%$ del total; sin embargo, es sumamente artificial considerar la importancia de esta ruta al margen del camino México-Guadalajara, pues ambas ciudades comparten la mayor parte del camino a la capital. ${ }^{33}$ Lo más exacto consistiría en evaluar la importancia del área comprendida entre estas tres ciudades.

De esta forma, la superficie bajo el triángulo que forman las ciuda-

33 Para evaluar la capacidad para importar mercancías de los sitios ubicados en esta ruta y evitar doble conteo con la ruta MéxicoGuadalajara no se tomaron en cuenta las receptorías de Cadereyta, Celaya, Salamanca, León, San Miguel, Querétaro, Guanajuato y Lagos, lo que sin duda es arbitrario. Sin embargo, como no hay posibilidad de diferenciar la gravitación específica de Guadalajara y Zacatecas en los sitios comunes se prefirio este procedimiento, bajo el riesgo de sobreestimar la importancia de las rutas hacia Guadalajara en detrimento de la que conduce a Zacatecas. En el límite del caso opuesto -más improbable porque Guadalajara es la segunda receptoría del país- la ruta hacia Zacatecas concentraría una quinta parte del total del reino. des de México, Guadalajara y Zacatecas aporta el 50\% del total nacional, constituyéndose así en el núcleo económico más importante de Nueva España.

El camino de Guadalajara a Sonora agrupa 5\% del total; la ruta ZacatecasChihuahua, el 3.5\%, existiendo en tal camino dos ciudades que figuran entre las primeras veinte: Durango y Chihuahua.

El camino México-Veracruz, finalmente, comprende alrededor de una cuarta parte del total, lo que lo convierte en el segundo camino más importante, debido básicamente a la aportación del comercio con España, el Caribe y la actual Venezuela. El puerto de Veracruz es la cuarta receptoría, Puebla la quinta, Orizaba y Córdoba las 11 y 12 , respectivamente.

La distribución del comercio en los caminos reales aporta uno de los elementos claves del papel de la ciudad de México en el comercio novohispano: su ubicación geográfica como centro de toda la red carretera colonial y principalmente, de los dos caminos más importantes: el del Bajio y Tierra Adentro, por un lado, y el de las importaciones desembarcadas en Veracruz, por el otro. Si a esto aunamos que el camino de Oaxaca-Chiapas y el principal camino de Acapulco terminaban en México, es fácil advertir el papel de la ciudad en el intercambio colonial. Papeles semejantes, a niveles locales, cumplían Guadalajara con el noroeste, Zacatecas con la Nueva Vizcaya y Oaxaca con el sur. La ubicación de estas ciudades como principales puntos de los caminos reales coloniales, es uno de los factores más impor- 
tantes a la hora de explicar la elevada concentración del comercio en unos pocos centros urbanos, entre los cuales la capital era el de rango superior.

\section{LA COMPOSICIÓN INTERNA DEL COMERCIO DE LA CIUDAD}

La concentración comercial en la ciudad de México entre 1770 y 1790 no abarcaba, desde luego, a todos los productos de una manera uniforme. La mayor parte de ésta estaba abocada al gran comercio internacional controlado por los mercaderes del Consulado de México, pues el $65 \%$ de las mercancías y productos que arribaron a la capital en el periodo $1770-1790$ provenían de otros países (cuadro 2 y gráfica 1). Únicamente el $35 \%$ restante

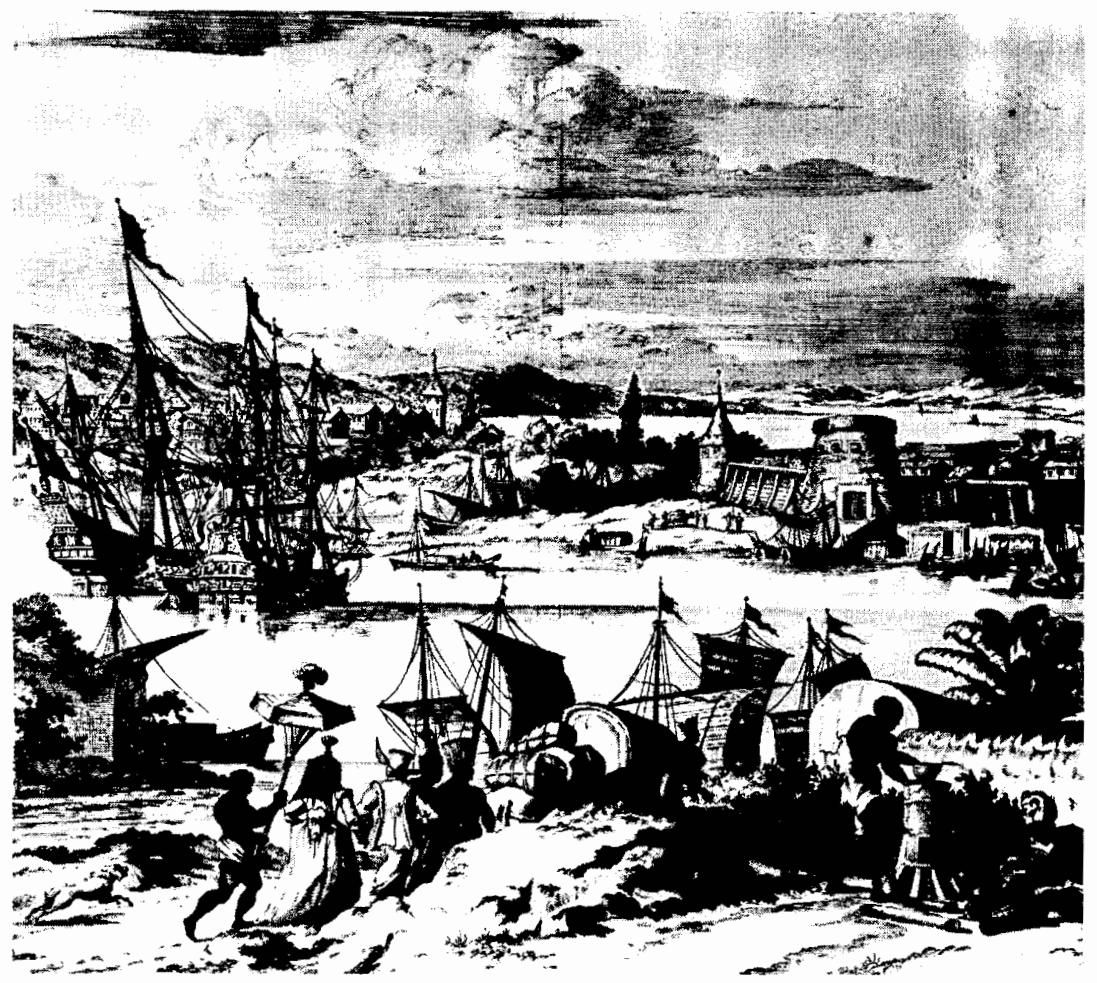

LA CALA Y GENERAL DEPóSITO DEL REINO 
₹ $888888888888888888888:$

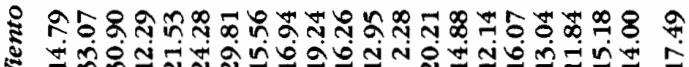

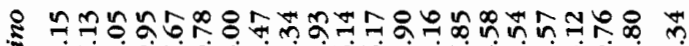

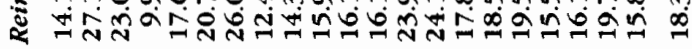

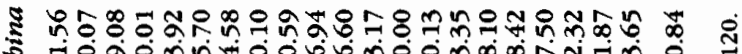

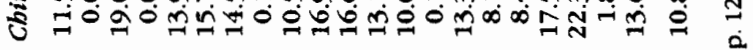

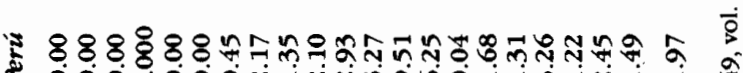
20000000NTiNinavontintiti

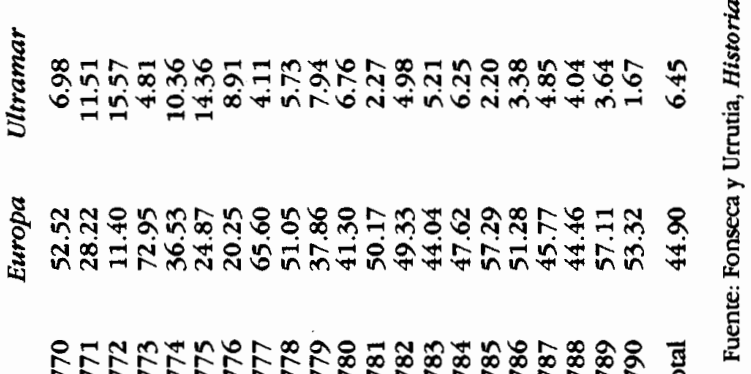

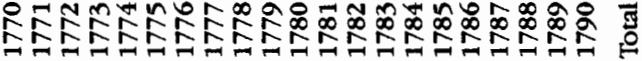




\section{SECUENCIA}

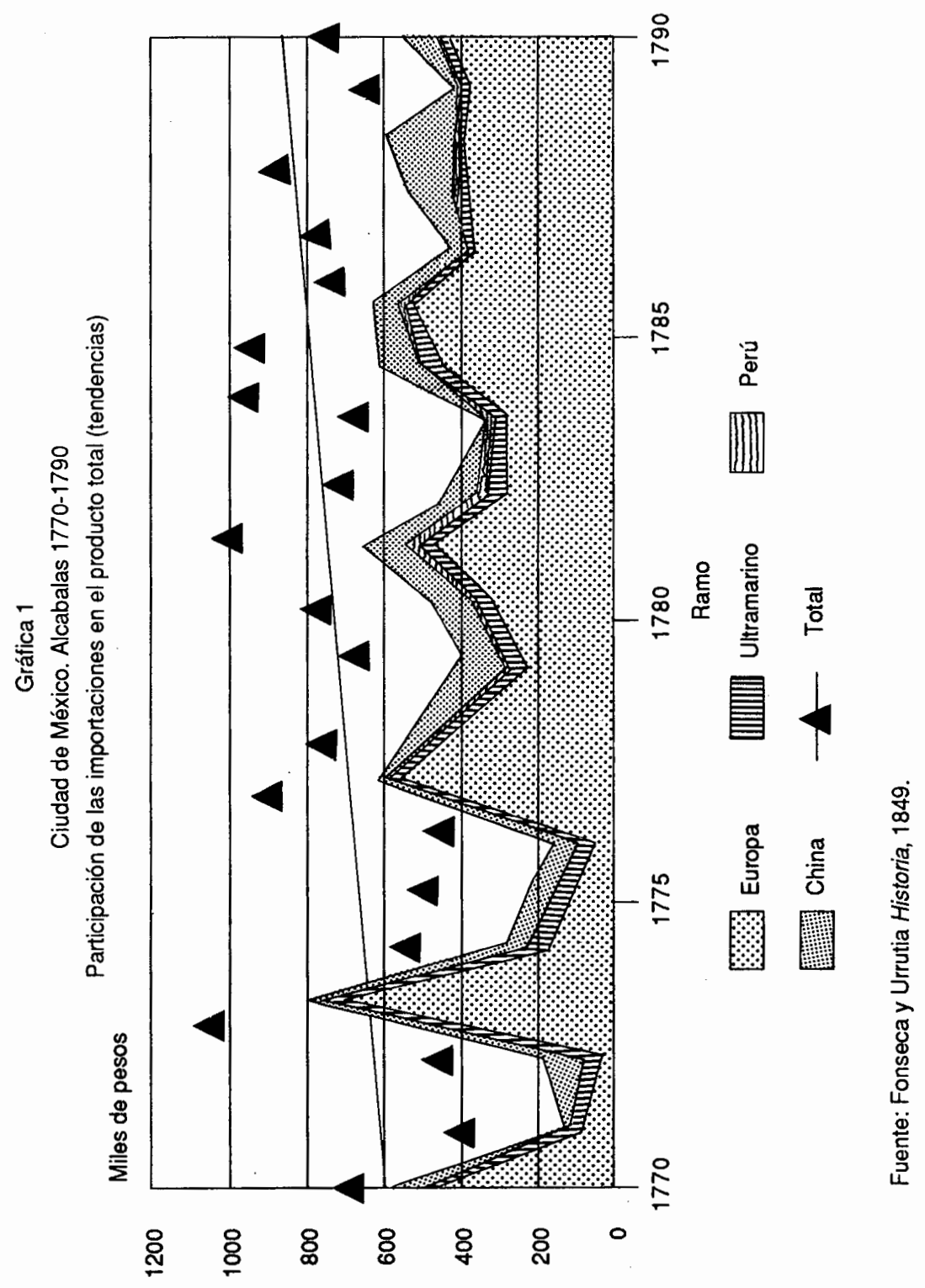


Cuadro 3.A

Importaciones totales de la ciudad de México en 1772

por grupo

Monto Facturas comerciantes c Porcentaje

Alimentos
Alimentos naturales
Alimentos procesados
Alimentos intermedios
Bebidas
Textiles
Ropa y vestido
Muebles y papel
Medicina y cosméticos
Cera
Vidrios y loza
Hierro y derivados
Efectos y géneros
Totales

Alimentos

$a$
91700
81952
816430
203760
43334
8605
60249
1363
152518
21288
949030
273877
896510

b

\begin{tabular}{|c|c|c|}
\hline & & \\
\hline 55 & 47 & 1.70 \\
\hline 41 & 38 & 1.08 \\
\hline 324 & 140 & 2.31 \\
\hline 112 & 62 & 1.81 \\
\hline 45 & 44 & 1.02 \\
\hline 8 & 8 & 1.00 \\
\hline 15 & 13 & 1.15 \\
\hline 8 & 8 & 1.0 \\
\hline 48 & 36 & 1.3 \\
\hline 16 & 16 & 1.0 \\
\hline 1400 & 800 & 1.7 \\
\hline 225 & 190 & 1.18 \\
\hline 969 & 644 & 1.5 \\
\hline
\end{tabular}

3.17

28.19

7.03

1.50

0.30

2.08

0.05

5.27

0.73

4.85

43.98

a/b: Número promedio de facturas por comerciante.

c: Número de comerciantes con más de una factura a su nombre.

Fuente: Archivo General de la Nación (AGN), Alcabalas de la ciudad de México: caja 4.

incluía productos de Nueva España. ${ }^{34}$ Sólo en 1772, cuando no hubo flota, las mercancias introducidas a la ciudad de México provenientes del interior de Nueva España, tuvieron un monto mayor a las venidas del extranjero. De este comercio exterior, una gran parte de los productos venían de Europa, esto es, el $45 \%$ del valor de todas las mercancías introducidas a la capital. En algunas ocasiones, como en 1773 ,

34 Estos porcentajes se obcuvieron sumando los rubros de Europa, Ultramarino, Perú y China de las mercancías introducidas a la ciudad en 1770-1790, por un lado, y los rubros de Reino y Viento por el otro. Fonseca y Urrutia, Historia, 1849, vol. II, pp. 120-121. el comercio de Europa alcanzó casi $75 \%$ del total.

El tráfico con las Filipinas representaba alrededor del $11 \%$ del total de la ciudad para 1770-1790, aunque en años como 1788 alcanzó hasta una quinta parte del total. Por otro lado, el comercio con el Caribe y Sudamérica fue en promedio del $8.5 \%$ y sólo en 1772 llegó a representar el 15\% del total.

Asi pues, la mayor parte de la hegemonía comercial de la ciudad de México obedecía, por ende, al control que ésta ejercía sobre el comercio exterior. De hecho, la composición de las alcabalas de la capital tenía una estructura anómala, y diametral- 


\section{SECUENCIA}

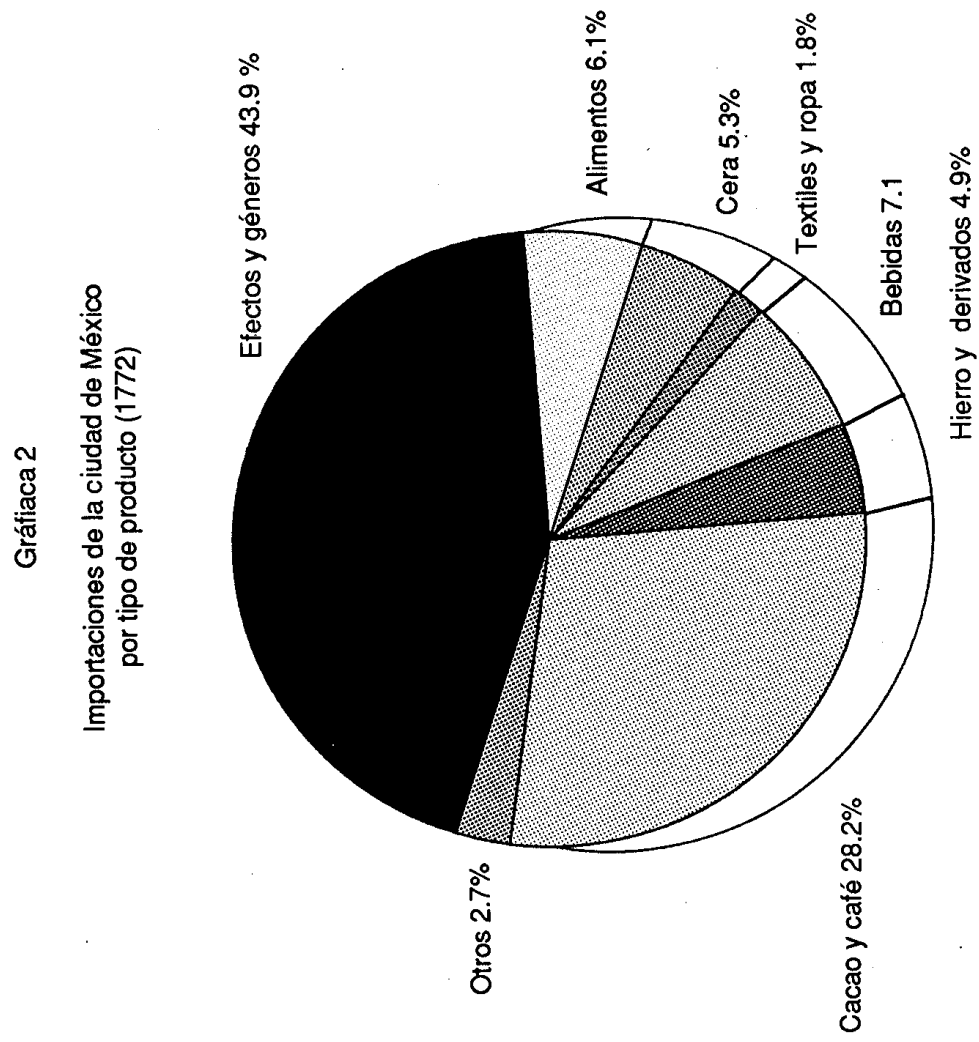

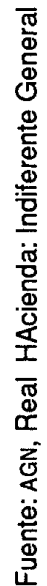


Cuadro 3.B

Importaciones totales de la ciudad de México en 1776

por tipo de producto

Monto Facturas Porcentaje Porcentaje

Alimentos
Alimentos naturales
Alimentos procesados
Alimentos intermedios
Bebidas
Textiles
Ropa y vestido
Muebles y papel
Medicina, cosméticos y cera
Vidrios y loza
Hierro y derivados
Efectos y géneros
Totales

248915
58724
402753
341976
95885
9568
380810
136146
30646
98630
856665
2660718

46
89
150
165
98
23
9
81
32
31
184
908

9.36
2.21
15.14
12.85
3.60
0.36
14.31
5.12
1.15
3.71
32.20
100.00

5.07

9.80

16.52

18.17

10.79

2.53

0.99

8.92

3.52

3.41

20.26

20.26

Fuente: AGN, Alcabalas, ciudad de México, caja 9.

mente opuesta a la existente en la Nueva España en general, pues, en esta última, los productos del exterior no llegaban al $30 \%$, lo que equivale a menos de la mitad de lo que por ese rubro ingresaba en la capital. 35

¿Qué tipo de productos importaba la ciudad del exterior?

Contamos con los libros de la Aduana de México para los años completos de 1772 y 1776 . Las importaciones de 1772 (año en el que el comercio con Europa aparece muy por debajo de su nivel normal, puesto que la flota se retrasó y llegó a Veracruz a principios de 1773) y 1776 , evidencian que, en gene-

35 Garavaglia y Grosso, Alcabalas, 1987, p. 48. Los autores presentan un cuadro para 1796 con la composición de las alcabalas de todo el reino. Según estos datos los rubros de Tierra y Viento suman más del $60 \%$, esto es exactamente lo contrario de to que sucedía con los productos que ingresaban a la ciudad de Mexico. ral, los comerciantes de México compraban en España, el Caribe, Filipinas y Sudamérica en forma alternada.

En 1772 la ciudad de México compró del exterior mercancías y procluc. tos por un valor en factura de casi 3000000 de pesos.

El $44 \%$ de ese valor correspondía a efectos y géneros de Europa y Filipinas, esto es a textiles y ropas principalmente (véanse cuadro 3.a y gráfica 2), el $28 \%$ a diferentes tipos de cacao y café, el $6 \%$ a alimentos naturales y procesados, el $7 \%$ a bebidas alcohólicas, básicamente aguardiente, y el 5\% a hierro y derivados. Otro $5 \%$ de las importaciones correspondia a las compras de cera.

En 1776, un año en el que la flota de España llegó a tiempo, la composición interna de las mercancías introducidas no varía mucho (véase cuadro 3. b) si bien presenta una distribución mucho 


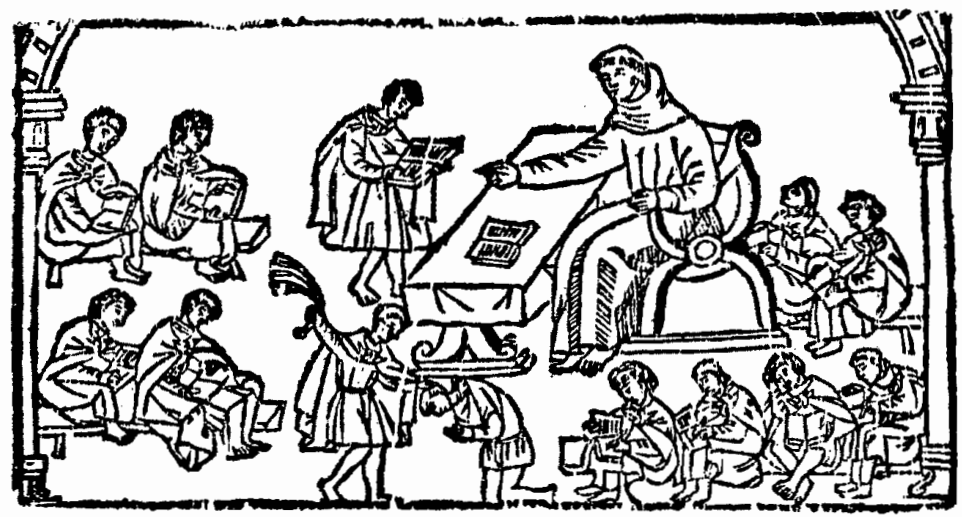

más balanceada: los efectos y géneros (textiles) tienen el 32\%, los alimentos naturales, el $9 \%$, el cacao y el café, el $15 \%$, los muebles y el papel, el $14 \%$, las bebidas alcohólicas, el $14 \%$, la cera, el $5 \%$, y el hierro, el 4 por ciento.

La mayoría de estos productos eran importados por un pequeño número de comerciantes, particularmente, el hierro, el cacao, la cera, el vino y el aguardiente.

La lista completa de productos ${ }^{36}$

36 Alimentos naturales: pimienta, clavo, especies, canela de China, azafrán, almendra; alimentos procesados: vinagre, salmón, sal de mesa, robalo de Campeche, robalo, pescado, pasas, frutas de Europa, alcaparras, aceitunas, aceite común; alimentos intermedios: cafe, cacao Tabasco, Soconusco, Santo Domingo, picado, Maracaibo, Guayaquil, de la Magdalena, colorado, Caracas; vino tinto, blanco, carlon, licor, cerveza, aguardiente; textiles: tripe, tafetán, seda china, sayales, ruanes, paños ingleses, de grana, paños de Castilla, mercería, menuclencias, listonería, listón, lamportes, hilo de muestra que las importaciones de la ciudad de México, estaban monopolizadas por un reducido número de grandes comerciantes.

acarto, hilo, estambre, escarlatas, capicholas de Europa, bretañas, bramantes, bayetas de Castilia; ropa y vestido: vestidos, sombreros, ropa de China, redecillas, pontivíes, medias de esambre, encajes, medias de China, camisas de Bretaña; muebles y papel: cajuelas de carey, papel de música, papel; medicina, raíces y cosméticos: ruibarbo, raíz de ipecacuana, polvo, palo de Campeche, medicinas, esperma de ballena, cera en bollos de Campeche, cera del norte, de La Habana, de Castilla, de Campeche, de China; loza y vidrios: vidrios romanos, de Alemania, cristales, vidrio común, loza de China, loza común; metálicos, básicos y procesados: metal de China, hierro, fierro, cobre, acero, rejas de arar, navajas de barbero, cuchillos, cuchillos belduques, clavazón, herrería; efectos, géneros y otros: cacerillos, piedras de tusil, peines de China, de carey, peines, géneros de Europa, China y comunes, fideos, efectos de Europa, China y comunes, coral, patíes, embreas, creas, cherlas de China, abalorio y alucemas. 


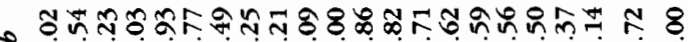

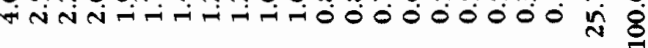

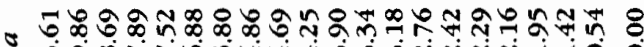

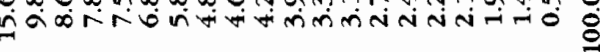

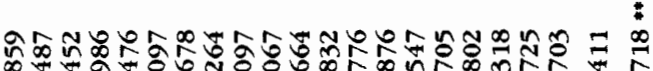

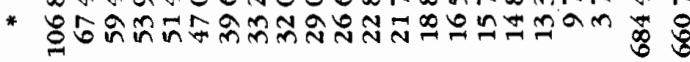

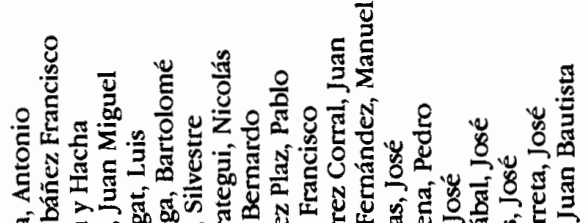

ㄴ.

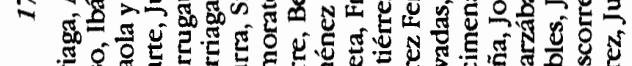

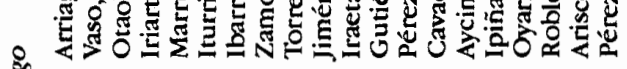

$\frac{1}{2}$

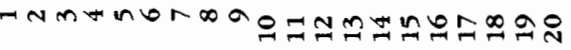

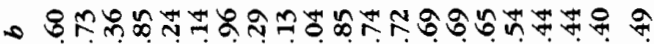

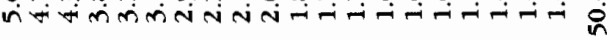

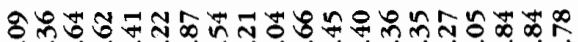

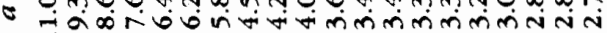
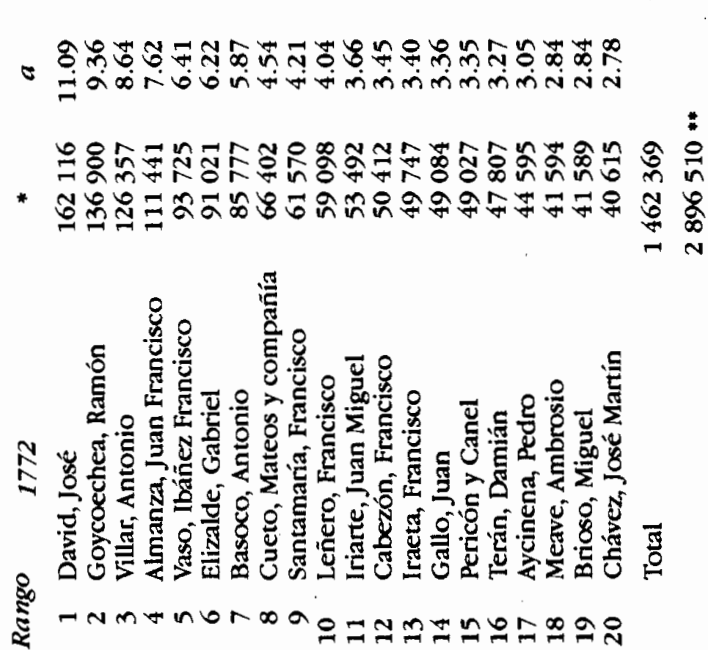

这

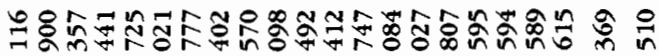

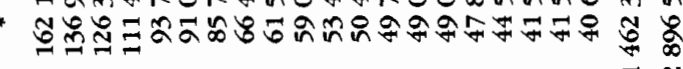

등 
Los introductores de estas mercancías eran los almaceneros del Consulado de México, quienes han sido objeto de numerosos estudios, ${ }^{37}$ que han abundado en sus conexiones políticas, sus empresas económicas y su influencia social.

La lista de introductores más importantes de la ciudad en ambos años (1772 y 1776) confirma la idea de que el gran comercio de la ciudad estaba en relativamente pocas manos. En 1772,20 personas (ver cuadro 4) controlaron la mitad de todo lo importado a la capital; en 1776, 20 introductores aportaron una cuarta parte de las im. portaciones totales.

El comercio con las Filipinas era prácticamente coto exclusivo de los comerciantes de México, como lo ha demostrado el estudio de Carmen Yuste. ${ }^{38}$ Según este trabajo, en las ferias de Acapulco de 1775, 1776 y 1778 , a los almaceneros de México correspondió el $85 \%, 92 \%$ y $95 \%$ del total de las inversiones. ${ }^{39}$

El comercio ultramarino imponía su lógica al comercio total de la ciudad, era el más importante y el más rentable.

Es claro que estos volúmenes de mercancías no encontraban su razón de ser en el consumo interno de la ciudad, pues era imposible que el $2.5 \%$ de la población del reino fuera capaz de importar para su consumo el $30 \%$ del tráfico de Nueva España.

El hecho de que la capital con-

37 Los más importantes son: Brading, Mineros, 1975; Borchart de Moreno, Mercaderes, 1984; Kicza, Empresarios, 1986.

38 Yuste, Comercio, 1984.

39 Ibid., p. 60. centrara a las elites burocráticas y eclesiásticas del reino, al igual que a las familias nobles más adineradas y a gran parte de las capas privilegiadas de la sociedad colonial, propiciando que la ciudad fuera un mercado cualitativamente distinto de los demás mercados regionales, no basta ni es suficiente para explicar la gran concentración de productos en la capital.

Según el censo de $1790-93$, la ciudad contaba con alrededor de 3500 eclesiásticos (regulares, monjes, monjas, beneficiados, etcétera); ${ }^{40}$ mientras que los burácratas y miembros de profesiones liberales no rebasaban los 2000.

Además, la gran parte del comercio de la ciudad no se dedicaba a artículos suntuarios ni de consumo inmediato, sino más a productos intermedios que debían ser procesados o simplemente almacenados, para venderse en los mercados del interior.

Esto ocurría por lo menos con el algodón, los textiles, el hierro, el acero, el cacao, el azúcar, el aguardiente, el cuero, la cera, el papel y otros más.

Es evidente, entonces, que los mercaderes de la capital colocaban la mayoría de sus mercancías en los mercados regionales de provincia, y que sus importaciones eran realizadas con vistas al abastecimiento de las ciudades del interior; es por ello que la estructura de importaciones de la ciudad de México antes mencionada, sigue exactamente la misma distribución que la

40112 monjes, 2168 monjas, 77 beneficiados, 34 vicarios, 43 sacristanes, 26 curas y 320 de otras clases y condiciones. AGI, Indiferente 1527. 


\section{Cuadro 5}

Productos de Nucva España introducidos a la ciudad de México, ramo de Reino (enero-octubre 1776)

\begin{tabular}{lrc} 
& Importe & Porcentaje \\
Algodón y mantas & 203094 & 17.43 \\
Ropa* & 144913 & 12.44 \\
Azúcar y panocha & 80455 & 6.91 \\
Rosarios & 71766 & 6.16 \\
Quesos & 60330 & 5.18 \\
Pescados y mariscos & 58467 & 5.02 \\
Jarcia & 56398 & 4.84 \\
Cobre y estaño & 56128 & 4.82 \\
Cueros & 42172 & 3.62 \\
Aceites & 36075 & 3.10 \\
Sayales & 32449 & 2.78 \\
Incienso, mirra y copal & 31030 & 2.66 \\
Añil & 30274 & 2.60 \\
Tecomates & 29360 & 2.52 \\
Metates & 27158 & 2.33 \\
Ajonjoli & 24402 & 2.09 \\
Plomo & 21658 & 1.86 \\
Sebo & 20255 & 1.74 \\
Alcaparrosa & 17111 & 1.47 \\
Chicle & 14615 & 1.25 \\
Grana & 14346 & 1.23 \\
Colchas & 13623 & 1.17 \\
Azafrán & 13183 & 1.13 \\
Chile & 12701 & 1.09 \\
Sombreros & 12412 & 1.07 \\
Petates & 11652 & 1.00 \\
Cera & 8796 & 0.75 \\
Liquidámbar & 8059 & 0.69 \\
Loza & 7704 & 0.66 \\
Cola & 4550 & 0.39 \\
Total & 165136 & 100.00 \\
\hline
\end{tabular}

* Sólo incluye jerga, paños, calcetas, rebozos y cortes de mangas.

Fuente: $\Lambda \mathrm{GN}$, Alcabalas, ciudad de México, 1776, Reino.

estructura de importaciones de todo el reino. $^{41}$

11 Las importaciones por tipo de producto para la Nueva España en el quinquenio 18021806: textiles $64.2 \%$, vino y aguardiente $10.4 \%$, cacao $5.6 \%$, papel $5 \%$, hierro y acero $4 \%$, y mis-
Por otra parte, los mercaderes de la capital hacían un gran intercambio

celánea $10.8 \%$; esto es prácticamente la misma distribución que seguían las importaciones de los mercaderes de la capital ya en 1772 y 1776. Brading, Mineros, 1975, p. 136. 
con las regiones del interior, que involucraba no solamente la plata de los centros mineros de Tierra Adentro y la grana para exportación de las regiones indígenas del sur, sino toda una amplia gama de productos que tampoco tenían en la ciudad de México su destino final.

Estos productos estaban contabilizados en el ramo de Reino.

Para la ciudad de México el ramo de Reino fue el segundo más importante en el periodo $1770-1790$, pues aportó en promedio el $18.3 \%$ del total de alcabalas de la capital, y sólo fue superado por el ramo de Europa.

Desafortunadamente, las series con las que contamos presentan pocas veces el nombre de los propietarios de las mercancías introducidas. Sin embargo, es posible identificar cuáles son los productos que más circulan, y cuál es su importancia en términos de su valor en factura.

Los productos más comunes que entraban en este rubro eran algodón, ropa, chile, azúcar, sebo, queso, panocha (piloncillo), vino, aguardiente, cera, ropa, pescado, ajonjolí y aceites.

Menos comunes, pero también frecuentemente nombrados, son productos como jarcia, cobre, camarón, alcaparrosa, sombreros, sal, loza, caña, copal, alumbre, plomo, cueros, paños, mantos. Mencionados eventualmente aparecen aceite de coco, chile pasilla, calcetas, fustes, rosilla, tabaco, granilla, cola, servilletas, jerga, estaño labrado, pedernal labrado, aceite de nabo, tecomates (vasijas), vidrios, pesiles, yesca, greta (grasa para vidriar el barro), palmilla (yuca), metates, añil, petates, jícaras, tablones, linaloe (xo- chicopal), quexquemiles (mantas de algodón) y zarza.

En el cuadro 5 aparece la distribución porcentual de este tipo de productos, procedentes de toda la Nueva España, introducidos a la ciudad de México para el año de 1776.

Curiosamente, al igual que sucedía con el comercio ultramarino, la mayor parte de estos productos no estaban destinados al consumo inmediato en la ciudad. Muchos de ellos servían como insumo de otros que finalmente eran remitidos nuevamente al interior del reino.

Por ejemplo, tenemos al algodón y las mantas, que representaban el $17 \%$ de las importaciones, constituyéndose así en el producto más importante del ramo de Reino. Este algodón cra destinado a las hilanderías, obrajes y cererías, para la elaboración de textiles, y cabos de vela, principalmente.

El tercer producto más importante, con el $7 \%$ del total, era el azúcar y el piloncillo, utilizados en la elaboración de las bebidas de chocolate y los dulces en general.

Los mercaderes de la capital tenían fuertes inversiones en los ingenios y trapiches del país, particularmente en las haciendas del actual estado de Morelos, donde fomentaron una considerable expansión comercial de la agricultura ${ }^{42} \mathrm{La}$ inversión azucarera constituyó una de las alternativas más usuales de los comerciantes de la capital en su intento por diversificar sus negocios. ${ }^{43}$

La ciudad de México era el principal

42 Martin, Rural, 1985, p. 104.

43 Ibid., pp. 114 y ss. 


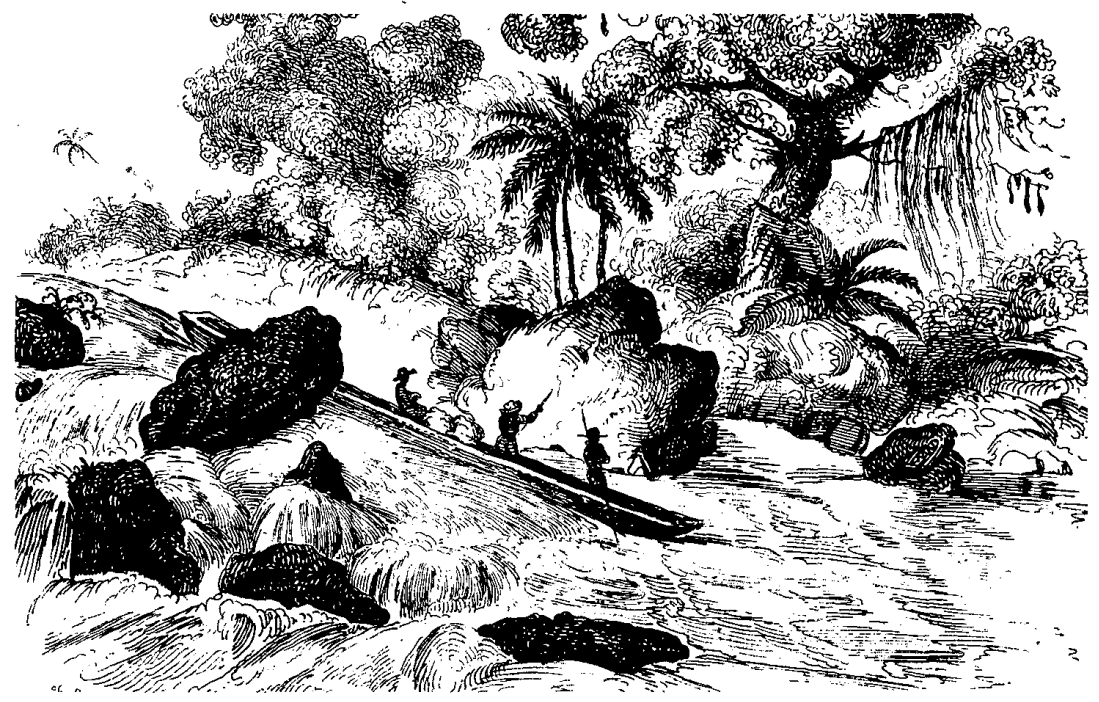

mercado del azúcar y del piloncillo de Morelos; ${ }^{44}$ los almaceneros de la capital financiaban y daban crédito a las haciendas azucareras, estableciendo con ellas una relación muy semejante a la que tenían con las minas. ${ }^{45}$

Otra gran variedad de productos introducidos eran los insumos de las manufactureras y talleres artesanales de la ciudad. Así, aparecen el cobre y el estaño (5\%), la jarciería (5\%), los cueros y los aceites (6\%), lo mismo que el añil, el sebo, el liquidámbar, la cola, la grana, el plomo, el chicle y otros.

De esta forma, muy pocos productos del ramo de Reino tenían que ver con el consumo directo de los ha-

44 Barrett, "Morelos", 1976, p. 161.

45 Ibid., pp. 166-167. bitantes de la ciudad. Para este fin, sólo aparecerían los quesos (5\%) y los pescados y mariscos (5\%). El caso de la ropa (12\%) no debe considerarse entre estos últimos, pues la mayoría de este renglón estaba formada por paños, cortes de mangas y jergas.

Un tercer grupo, de importancia mínima, lo forman productos terminados y destinados a los pequeños mercados de la ciudad. Así se explica la presencia de incienso, mirra, copal, sayales, tecomates, metates, petates, sombreros, etcétera, ninguno de ellos con más del $2.7 \%$ del total.

Algunos productos se contabilizaban aparte, y pueden dar algunas pistas de la participación de la ciudad en el mercado nacional. En el caso del aguardiente nacional, por ejemplo, tenemos las rentas totales del rei- 
Cuadro 6

Nueva España 1797-1800 participación porcentual de la ciudad de México en las introducciones de aguardiente nacional

\begin{tabular}{rrrrrrrrrr} 
& \multicolumn{4}{c}{ Ciudad de México } & \multicolumn{3}{c}{ Nueva España } & \multicolumn{3}{c}{ Participacion } \\
& Indulto & Alcabala & \multicolumn{1}{c}{ Total } & Indulto & Alcabala & Total & Indulto & Alcabala & Total \\
1797 & 22151 & 25321 & 47472 & 49086 & 174253 & 222339 & 45.13 & 14.53 & 21.35 \\
1798 & 24177 & 34812 & 58990 & 43072 & 198149 & 241221 & 56.13 & 17.57 & 24.45 \\
1799 & 21860 & 36103 & 57933 & 178530 & 50114 & 228649 & 12.24 & 72.04 & 25.34 \\
1800 & 23233 & 32044 & 55278 & 174315 & 142439 & 216754 & 13.33 & 22.50 & 25.50 \\
& 91422 & 128282 & 219705 & 445964 & 465153 & 911118 & 20.50 & 27.58 & 24.11
\end{tabular}

Fuente: AGN, Alcabalas, ciudad de México: varias cajas.

no entre 1797 y 1800 , lo mismo para la ciudad. El aguardiente tenía mucha demanda en los centros mineros del norte del país, al igual que en el resto de las ciudades y pueblos. Además era un producto cuyo traslado a largas distancias, no implicaba un excesivo aumento en los fletes de transportación. ${ }^{46}$

La ciudad de México entre 1797 y 1800 concentró el $27 \%$ del total de las introducciones de aguardiente americano de Nueva España (ver cuadro 6).

De esta forma, podemos concluir que el ramo de Reino estaba íntimamente involucrado con las necesidades del gran comercio de la ciudad, y muy poco ligado al suministro de alimentos básicos del mercado interno de la capital.

\footnotetext{
46 Sobre las condiciones de transporte $y$ costo de los fletes para el camino de Tierra Adentro, y particularmente el camino de Chihuahua en el siglo xviI, véase Hadiey, Minería, 1979, pp. 114-123. En condiciones ideales, señala el autor, el viaje en carreta o con una recua de México a Chihuahua tardaba de 3 a 4 meses. Las mercancías seguían el viaje hasta Santa Fe de Nuevo México, distante otros $950 \mathrm{kms}$, para lo cual se necesitaban de $\mathbf{4 0}$ días a 2 meses más.
}

La mayoría de estos productos, después de una previa transformación en los talleres y pequeñas industrias de la ciudad, salían de ésta para ser transportados y finalmente vendidos por los comerciantes mayoristas de la ciudad.

\section{El abasto de la ciudad}

Aunque la ciudad tenía un binterland más o menos delineado desde la época precolombina, fue a fines del siglo XVI cuando la capital subordinó una zona claramente demarcada para su abasto y suministro agrícola y ganadero. ${ }^{47} \mathrm{La}$ definición de esta área de influencia fue posible por el reemplazo de los medios de transporte terrestre indígenas por los europeos y a la utilización intensiva del sistema de canoas y trajineras para el traslado acuático de granos y materias primas. ${ }^{48}$

La combinación de los medios de transporte indígenas lacustres con los medios terrestres españoles, así como

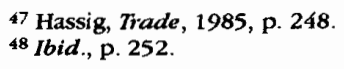

47 Hassig, Trade, 1985, p. 248.

48 Ibid., p. 252. 
la ubicación de la ciudad en el centro de una amplia zona acuática, hizo posible que el mercado urbano definiera su zona de abastecimiento e integración regional en forma temprana, ${ }^{49}$ en comparación con otras ciudades del reino. ${ }^{50} \mathrm{La}$ mayor parte de las ciudades de Nueva España desarrollaron un mercado regional tardío; ni siquiera en graves momentos de escasez y crisis agrícola fueron capaces de generar un abastecimiento considerable desde otros puntos del reino. ${ }^{51}$

Esta disparidad con el tiempo en que las ciudades coloniales configuraron sus áreas agrícolas y ganaderas de abastecimiento, sólo hasta recientemente ha llamado la atención de los historiadores. 52

La ubicación lacustre de la capital, y el uso sistemático de transporte en canoas (más barato y eficiente que el terrestre) ofreció ventajas adicionales al abastecimiento del mercado urbano, no sólo por la disminución de los costos de traslado, sino sobre todo, por la ampliación del radio de abasteci-

49 Ibid., p. 266.

so Véase el área de abastecimiento de maíz, trigo y came de la capital a fines del siglo xvi en Hassig, Trade, 1985, pp. 248-249; y la correspondiente a Guadalajara a fines del xvil en Van Young, "Urban", 1979. Mientras que la primera incluye los valles de Toluca, Atlixco, Puebla y Tlaxcala, la segunda se reduce a un "óvalo de 100 por 200 kilómetros sin alcanzar a cubrir zonas cercanas como La Barca, Teocaltiche o Jalostotitlán, que caían en las esferas de Valladolid, Aguascalientes y el Bajio respectivamente, ibid, pp. 601-602. Para el caso de Oaxaca entre 1750 y 1820 , véase Hamnett, "Dye", 1971, p. 52.

sl Ouweneel y Blijleveld, "Economic", 1989, p. 487 .

52 Bronner, "Urban", 1986, p. 20. miento y la mayor consolidación de un mercado regional.

6

[...] Si los productores de maíz -señala John Coatsworth- hubiesen logrado embarcarlo en Guanajuato, a los mismos precios pagados por embarque en canoa en los lagos que rodean a la ciudad de México, el radio de abastecimiento de Guanajuato habría aumentado [de 55] hasta entre 485 y 725 kilómetros $[\ldots]^{53}$

Contando pues, la ciudad de México, con ventajas naturales y sociopolíticas para la configuración del más extenso y temprano binterland de localidad colonial alguna, su aprovisionamiento satisfacía adecuadamente sus requerimientos de bienes de consumo para su población y materias primas para su artesanado.

A través del ramo de Viento se contabilizaban las entradas de harinas, carneros y reses, cebada, cerdos, lanas, pieles, especias y semillas.

Existía un rubro llamado Testimonios, donde aparecían el impuesto cobrado por venta de inmuebles y esclavos.

Aunque el ramo de Viento no representa exactamente al consumo de la ciudad, pues hay productos (pulque, maíz, aguardiente, etc.) que no aparecen y otros (venta de esclavos, transacciones inmobiliarias, etc.) que no tienen que ver con el suministro de alimentos y materias primas, ${ }^{54}$ su estu-

53 Coatsworth, Origenes, 1990, p. 94.

54 Garavaglia y Grosso, Alcabalas, 1987 y "Marchands", 1989 han investigado exhaustivamente esta relación entre el ramo de Viento y el consumo del suelo alcabalatorio, ofreciendo 


\section{SECUENCIE}
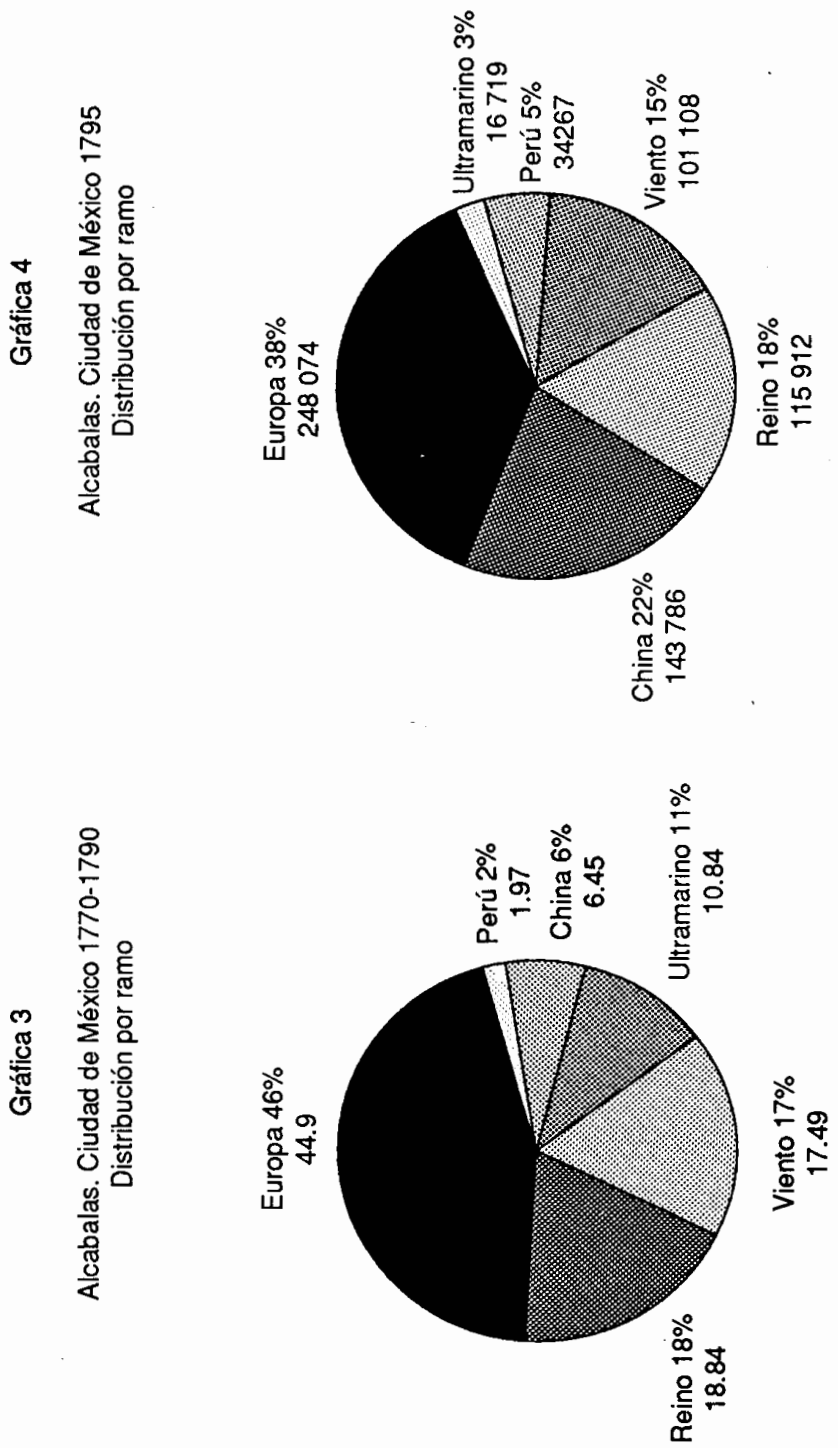

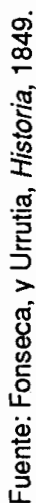


dio nos ofrece una idea aproximada del abasto de la ciudad.

Para el análisis contamos con el registro detallado del total de productos introducidos a la ciudad en el año de 1795.

Para la época de nuestro interés, el año elegido es altamente representativo en el ramo Viento, puesto que la distribución porcentual de éste en el total de alcabalas es prácticamente la misma (15\% en 1795 y $17 \%$ en el periodo $1770-1790$ como se puede apreciar en las gráficas 3 y 4). Por otra parte, no tenemos elementos para suponer que el sistema de abastecimiento hubiese sufrido grandes cam. bios entre ambas fechas.

Una amplia variedad de 85 produc. tos son registrados en este ramo, destacando los arriba señalados. ${ }^{55}$

incluso ejemplos sobre cómo obtener una estimación confiable del consumo de una localidad a partir de este ramo.

55 La lista de productos es la siguiente: aceituna, alberjón, alfajías, arenilla, arenilla de pedernal, arroz, arroz de la costa, de Apatzingán, badanas, baqueras, cacahuate, cabritos, cal, carne de puerco, carneros, cascalote, cáscara, cecina, cebada, chía, chicharrón, chito, cilantro, coco, coco de aceite, coco de agua, comino, costales, cueritos, dátiles, frijol, garbanzo, haba, harina, harina flor, jamon, jenjibre, lana, lardo, lechones de varias calidades, lentejas, linaza, madera, manteca, miel, morillos, mostaza, morriñas, nabos, nueces, ocre, ollas, palmas, pepita, pepita de melón, piedra, pieles, piña, plátano pasado, pudrición, quesos, recintos, tajamanil o tejamanil, terneras, tezontle, toros, vacas, yeso y, finalmente, zaleas.

Algunos productos arriba citados requieren ser aclarados: cáscara es una corteza medicinal; cascalote es la vaina de la planta caesalpinea que se empleaba para curtir; la baqueta es un tipo de piel; el chito es carne de chivo o carnero frita en su propio sebo; lardo es grasa de sebo; tajamaniles son tiras delgadas de madera de oya-
Al contrario de lo que sucedía en otros ramos, el comercio de viento estaba en manos de un gran número de comerciantes e introductores, la mayoría de ellos mercaderes al pormenor.

Según nuestros datos, en 1795 entraron mercancías en 14200 guías a nombre de 1547 introductores, esto es, aproximadamente nueve guías por comerciante, lo que habla de la amplia distribución en las introducciones de estos productos.

No obstante hay mercancias que se acaparaban. Entre ellas destacan los carneros, que eran introducidos por 50 comerciantes, de los cuales tan sólo seis abastecían el 98\% del mercado. Antonio Bassoco por ejemplo introdujo a su nombre el $35 \%$ del total anual. Gabriel de Yermo, el 21\%, Ángel Puyade y Vicente Urízar, el 12 y $11 \%$ respectivamente, mientras que la marquesa del Jaral y el marqués de San Miguel introducían el resto. Así todo el abasto de carneros a la ciudad estaba en manos de seis personas, resultando ser el rubro más importante de todo el ramo, concentrando más de la cuarta parte del ingreso por derechos de aduana.

El cuadro 7 presenta la distribución de las entradas del ramo Viento en ocho rubros (véase también la gráfica 5). La introducción de harinas representaba otra cuarta parte del ramo, y su suministro a la ciudad corría a cargo de más de 120 pequeños co-

mel o abeto utilizadas para techar las casas; badanas son pieles curtidas de carnero o de oveja; alfaljía es un madero de sierra usado para marcos y largueros de puertas y ventanas; zalea se refería a cualquier cuero o piel en general. 
Cuadro 7

Ciudad de México 1795 ramo de Viento, entradas

\begin{tabular}{lrc}
\multicolumn{1}{c}{ Mercancias } & Derechos & Porcentaje \\
Harinas & & \\
Cebada & 25327 & 25.0 \\
Cerdos & 518 & 0.5 \\
Lanas & 16207 & 16.0 \\
Semillas-especies & 2382 & 2.4 \\
Carneros & 12312 & 12.2 \\
Baquetas y pieles & 27832 & 27.5 \\
Testimonios & 4475 & 4.4 \\
Totales & 12055 & 11.9 \\
& 101108 & 99.9
\end{tabular}

merciantes, que por lo general introducían muy reducidas cargas. Ninguno de ellos concentró más del $4 \%$ de toda la harina importada. ${ }^{56}$

Prácticamente lo mismo sucedía con la cebada, cuya introducción quedaba en manos de 180 personas distintas, con guías casi siempre menores a las 100 cargas por introductor; el destino principal de la cebada era para consumo de las mulas, aunque hay noticias de que una mínima porción era alimento de la gente. 57

Asi, el suministro de cereales a la ciudad descansaba sobre un amplio conjunto de pequeños comerciantes que, por su cuenta, llevaban a la capital pequeñas y constantes cantidades de harina y cebada.

El abasto de cerdos estaba en manos de alrededor de 300 pequeños in-

56 Garavaglia y Grosso, "Marchands”, 1989, p. 572 encontraron la situación opuesta al analizar el abasto de harina en Tepeaca, donde 4 comerciantes controlaban, en 1792 , el $80 \%$ del total de la producción.

57 "Informe...", f. s/n., AGI, México, 2094. troductores. Domingo Diana, el mayor comerciante de cerdos y lechones, apenas introdujo el $2 \%$ del total anual. La importación de cerdos y lechones representaba el 16\% del valor del ramo de Viento. Su utilidad residía no únicamente en el consumo alimenticio, el sebo y la piel del puerco se empleaban en la fabricación de velas, aceite y jabones.

Las lanas estaban igualmente distribuidas a cerca de 80 comerciantes, entre los que no había un introductor que destacara de los demás. El comercio de lanas no tenía un peso importante en el abasto interno de la ciudad y en 1795 apenas aportaba el $2.4 \%$ del total. ${ }^{58}$

En semillas y otras especies, esto es frijol, arroz, cacahuate, cal, carne cortada de cerdo, jamón, cecina, cascalote, comino, lenteja, chicharrón, chito, garbanzo, madera, manteca,

58 En Tepeaca, casi el $60 \%$ de la lana era introducida por 4 comerciantes. Garavaglia $y$ Grosso, "Marchands", 1989, p. 572. 


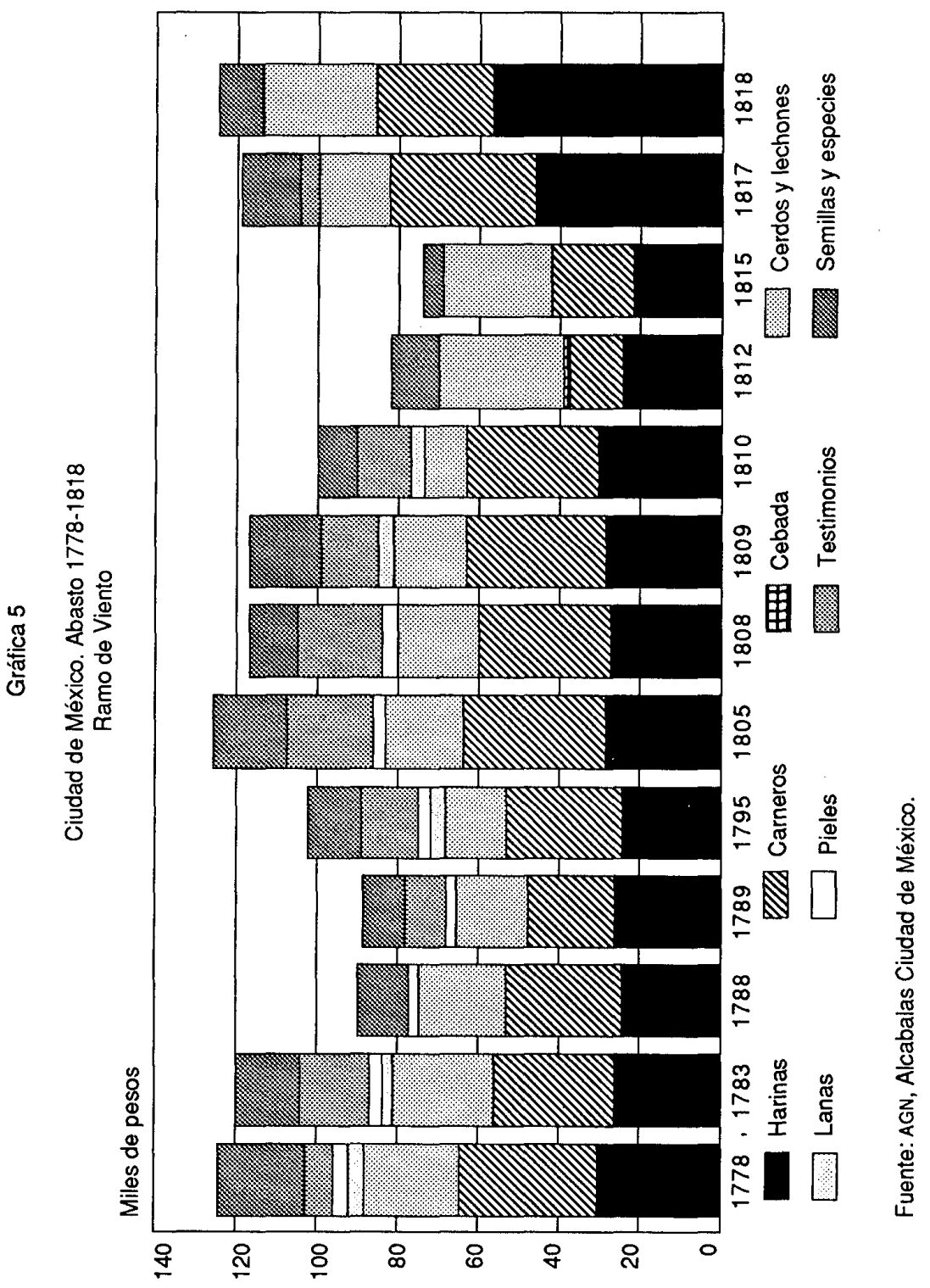




\section{SECUENCIG}

\section{Gráfica 6}

Nueva España. Alcabalas 1778-1791

Distribución por intendencia

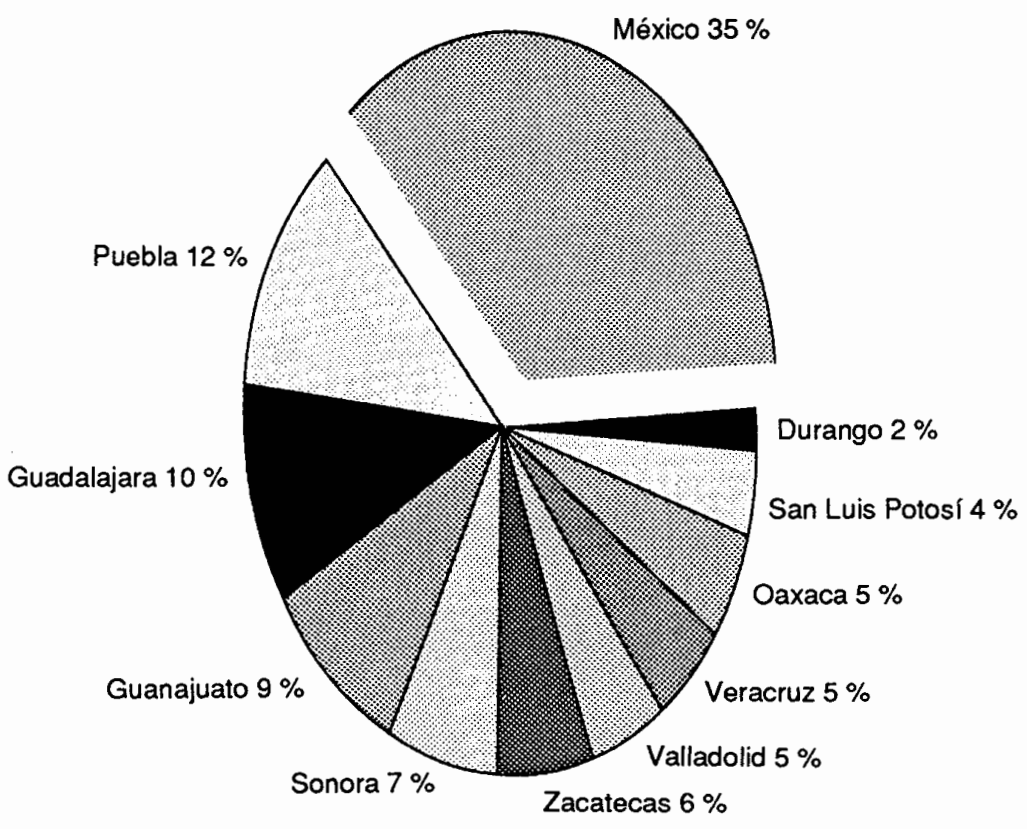


miel, piedra, quesos, yeso, tezontle, tejamanil, etc., radica el gran pequeño comercio de la ciudad, pues comprende más de 1100 comerciantes, si bien su valor no representa más del 12 por ciento.

En el abasto de frijol participan alrededor de 200 pequeños comerciantes, que se repartían igualitariamente las cuotas de introducción. Lo mismo sucedía con el arroz, el cacahuate, la cal, la cecina, el jamón, la manteca y la mayoría de los alimentos menciona. dos anteriormente.

No ocurria esta diversidad de comerciantes en todos los productos. La madera, por ejemplo, estaba en manos de sólo cuatro personas: Francisco Alba, Vicente Arroyabe, Pedro Cortada y José Tirado. La miel, por su parte, estaba bajo el control de una veintena de introductores. Cosa semejante sucedía con los quesos. Pero quizá el único producto en este ramo, cuya introducción estaba monopolizada era la piedra para construcción, donde tres personas remitían tres cuartas partes del abasto. Finalmente, el suministro de cueros estaba equitativamente distribuido. Los cueros y pieles se utilizaban para la fabricación de zapatos, cintas, zurrones, tirantes de coches y calesas, cinturones; pero sobre todo, para el trabajo en las minas y haciendas de beneficio de plata. ${ }^{59}$

El análisis del abasto de Viento en la ciudad de México, muestra una estructura de suministro, sobre todo, de alimentos, claramente distinta de aquéllas detectadas en el manejo e

59 Hadley, Mineria, 1979, p. 124.

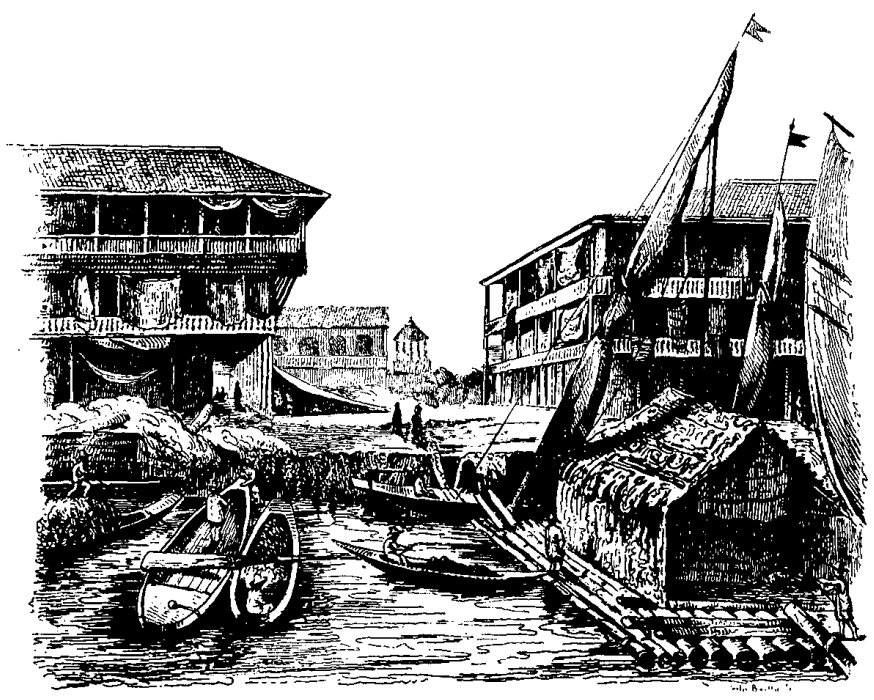


introducción de las mercancías del gran comercio, abocado a los mercados locales del camino de Tierra Adentro, vinculado a las importaciones de España, Sudamérica y Filipinas. A diferencia de estos últimos, el comercio que abastece las necesidades alimenticias y de vivienda de la capital, presenta una red de suministro conformada por un sinnúmero de pequeños introductores, quienes desde luego realizan sus compras en las áreas colindantes de la ciudad y en centros agrícolas próximos.

Así pues, muy pocas semejanzas se observan entre la manera en que la ciudad importa las mercancías, para satisfacer su denianda interna, y aquella en la que introduce los productos que serán transformados y remitidos a otros lugares de Nueva España.

Es por ello que la importancia porcentual del ramo de Viento, sí tiene una correspondencia con el peso demográfico de la ciudad. Entre 1778, por concepto de Viento, ingresó a la capital el $4.7 \%$ del valor total de alcabalas para Nueva España, valor que casi duplica el porcentaje de $2.5 \%$ que absorbía de la población total del reino.

Que la capital consumiera casi el doble, se explica por la circunstancia ya antes señalada de que en esta ciudad se ubicaba un mercado interno cualitativamente distinto, dada la fuerte concentración de burócratas, nobles, profesionistas libres y eclesiásticos. Así pues, el análisis del rubro de Viento confirma la naturaleza comercial de la ciudad no en tanto gran consumidora, sino como gran intermediaria y distribuidora de los productos nacionales y extranjeros.

LA CALA Y GENERAL DEPÓSITO DEL REINO

\section{CONSIDERACIONES}

La concentración de los productos comercializables en manos de los almaceneros de la ciudad de México, seguía diversos patrones de selección y tipo de mercancías.

Dicha concentración pues, no era homogénea a todos los productos ni podía ser identificada solamente con las mercancías que venían de Europa.

Algunos productos estaban mucho más acaparados que otros. Buen ejem. plo de ellos es el aguardiente importado y nacional. Entre 1797 y 1800 , los comerciantes de la capital introdujeron a la ciudad una cuarta parte de todo el aguardiente existente, del cual, sólo una mínima porción estaba destinada al consumo interno, en tanto que la gran mayoría iba a ser embotellado y remitido al interior del país para su posterior venta. ${ }^{60}$

Otro ejemplo lo forman el cacao y el azúcar, importados en grandes cantidades, los cuales, mezclados, se utilizaban para elaborar una bebida ampliamente difundida entre la gente pobre del reino, el chocolate. ${ }^{61}$

Un informe de $1749^{62}$ sobre los frutos y semillas que entraban a la

60 Pocos trabajos han seguido la ruta del aguardiente, cuyo consumo parece haber sido eminentemente urbano y estrechamente ligado en su distribución a los centros urbanos situados en las rutas comerciales, Taylor, "Town", 1976, p. 92, encontró dicho patrón en los valles de Oaxaca.

61 Florescano y Castillo, Controversia, 1975 , vol. I, pp. 125 y ss. y 176 y ss.; Arcila Farías, Comercio, 1975 , p. 39.

62 "Relación de los efectos y frutos sobre los cuales recae en México...", f. s/n., AGI, Mexico, 2094. 
ciudad, estimaba que la capital adquiría dos terceras partes del total del cacao producido en el reino $o$ importado de fuera. Los comerciantes de la capital novohispana tenían una sólida demanda de cacao en las plantaciones venezolanas, independiente en monto e importancia de la demanda peninsular. ${ }^{63}$

Cosa semejante ocurría con la cera de Campeche, donde la mitad de la producción según este mismo informe iba a dar a los grandes almacenes de la capital. Sin embargo, la mayor parte de las velas no estaba hecha con cera, sino con grasa animal, de cerdos, chivos, ovejas y vacas. ${ }^{64}$ Dicho informe concluía con cierta exageración: sostenía que cinco sextas partes de todo lo que se comerciaba pasaban por la ciudad de México, pues ésta era la la caja y general depósito que surte a todas las protincias. ${ }^{65}$

En 1788 los comerciantes del Consulado de México informaban al rey una estimación referida a la concentración de las mercancías procedentes de España:

[...] Es cómputo bien común que de todo lo que viene de España entra la mitad en la capital de México, ya por cuenta de los cargadores europeos, ya por la de los vecinos del reino que los adquieren de aquéllos. Esta mitad del todo no la consume México ni sus habitantes, y es cosa clara y bien experimentada que la mayor parte vuelve a salir para otros lugares del reino [...] lo mismo que hemos informado res-

\footnotetext{
63 Piñero, "Cacao", 1988 , p. 91.

64 "Informe...", f. s/n., AGI, México, 2094.

65 "Relación...", f. s/n., AGI, México, 2094.
}

pecto de México acaece con lo que se introduce en Puebla, Guadalajara, Querétaro, Valladolid y demás principales ciudades del reino, que tampoco consumen la mitad de lo que se les introduce, porque el surtimiento que se destina a ellas se hace con el objeto de proveer a otros lugares menores, de que también se abastecen otros más pequeños $[. .]^{66}$

A juzgar por nuestros datos, es probable que la parte de los productos que volvían a salir de México era mucho más que la mitad, si bien la mayoría de estos productos salían hacia las provincias ya elaborados, esto es como bienes de consumo terminados para ser vendidos en los mercados regionales de Nueva España.

Es por ello que el papel preponderante que jugaron los comerciantes de la ciudad en la economía colonial, a fines del virreinato, se explica también en función de una creciente protoindustrialización de las actividades laborales de la población de la capital, ${ }^{67}$ sobre todo, en la segunda mitad del siglo XVIII, cristalizada en una especialización de la población activa en actividades artesanales, manufactureras y fabriles.

En 1790 la ciudad de México tenía aproximadamente 110000 habitantes, según el censo de Revillagigedo. ${ }^{68}$

Para la misma fuente la ciudad

66 "Informe del Consulado de Comerciantes de México al rey, sobre la situación del comcrcio y la economía de Nueva España" (1788), Florescano y Castillo, Controversia, 1975, vol. I, p. 101.

67 Ouweneel y Blijleveld, "Economic", 1989, p. 497.

${ }^{68}$ AG I, Indiferente, 1527, f. s/n. 
contaba con más de 8000 artesanos, cerca de 1500 fabricantes y alrededor de 1300 comerciantes.

Artesanos y fabricantes representaban el 33.3\% de la población mascu. lina mayor de 16 años y el $14 \%$ de la población civil mayor de 16 años (hombres y mujeres).

Los comerciantes, por su parte, eran casi el $5 \%$ de la población masculina adulta.

El artesanado era la ocupación más importante en términos cuantitativos, sólo superada por los cerca de 9000 indios tributarios de las parcialidades.

Los datos que John E. Kicza encontró para prácticamente el mismo periodo -basados en el Censo de los gremios de la ciudad de Méxicoconfirman la hegemonía de la industria artesanal como principal actividad económica de la ciudad. Según la fuente citada, en la capital había más de 10000 artesanos calificados, entre los que destacaban tejedores e hilanderas de seda, sayaleros, algodoneros, veleros, bordadores, sastres, herreros, carroceros, fundidores, plateros, listoneros, cordoneros, zapateros, curtidores, cereros, loceros, tintoreros y doradores. ${ }^{69}$

En opinión de Kicza, entre un tercio y la mitad de los habitantes de la ciudad dependían económicamente de las actividades artesanales.

Algunas de estas manufacturas estaban directamente asociadas a la pro. ducción de los artículos que más fácilmente colocaban los comerciantes de la ciudad en los mercados del interior del país, particularmente los talleres

\footnotetext{
69 Kicza, Empresarios, 1986, p. 228.
}

que trabajaban el hierro, la seda, las pieles, el cuero, la cera, el algodón, y los textiles en general.

Los talleres de herrería, por ejemplo, estaban íntimamente ligados a la vida comercial de la ciudad, con vínculos muy estrechos con el capital comercial, que fue el principal causante de que a fines del siglo xvil tales talleres evolucionaran " $[\ldots]$ hasta convertirse en empresas muy grandes, que contenian varias forjas y estaban valuadas en miles de pesos [...]"70

Otro caso lo constituye el gremio de los algodoneros, que contaba en 1796 con 353 telares; si bien en sus comienzos podían no estar asociados con los comerciantes, casi siempre terminaban por solicitarles inversiones y préstamos, debido a la baja capitalización de sus talleres. ${ }^{71}$

Grandes rebaños eran conducidos a la capital, a veces desde Coahuila, como insumo de las manufacturas y los textiles. ${ }^{72}$

El trabajo del algodón, la seda y los textiles en general propicio el florecimiento de un buen número de pequeñas hilanderías y sederías, muchas de ellas trabajadas por mujeres, que maquilaban las piezas y confeccionaban buena parte del monto importado a la ciudad. Algo muy semejante sucedió con la manufactura del hierro, las pieles y el cuero.

No contamos con una serie estadística completa de las remisiones de los comerciantes de la capital a sus clientes y representantes del interior

\footnotetext{
${ }^{70}$ Ibid., p. 237.

71 Ibid., p. 241.

72 Brading, "Comments", 1989, p. 532
} 
del reino, que permitan emprender un análisis más sistemático; existen un sinnúmero de registros de envíos de particular a particular que, cuando menos, hacen posible ejemplificar la transformación artesanal que sufrían las materias primas que arribaban a México.

Entre 1797 y 1800 Antonio Oscola -por ejemplo- remitía gran parte de sus mercancías a los reales mineros de Sombrerete, Fresnillo y Guanajuato. Los principales productos eran ropa, sombreros, cacao, vino, aguardiente, aceite, mantas, hierro, herramientas, pabilo, pescado seco y cera. ${ }^{73}$

Ramón Goycoechea, quien introdujo en 1772 casi el 5\% de las importaciones de la capital:

[...] mantuvo un acuerdo comercial con un tratante de la población minera de Sierra de Pinos durante varios años. Goycoechea le proveía de todos sus artículos, recibía toda la plata que aquél reunía, pagaba todas las libranzas (órdenes de pago) que expedía y garantizaba todos los pagos que hacia $[\ldots]^{74}$

Ramón Ibarrola remitía a Chihuahua chocolate, aceite, merceria, seda, ropa, rebozos, sombreros, cera labrada, herramientas de hierro, chicle, peines, utensilios de cocina, papel, zapatos, mantas, alcohol, calcetines y telas. ${ }^{75}$

Jerónimo Varela enviaba al puerto de Acapulco almidón, anís, herrajes, li-

73 "Cuadernos de remisiones", AGI, Alcabalas de la ciudad de México, caja 12, exp. s/n.

74 Kicza, Empresarios, 1986, p. 102.

75 AGI, Alcabalas de la ciudad de Mexico, caja 4, exp. $s / n$. quidámar, aceite, almendras, zapatos, cuchillos y navajas, especies, acero, chile, rebozos, papel, aguardiente, cuerdas, mercería, esperma de ballena, etcétera. ${ }^{76}$

Francisco Rosete remitía a Acapulco también jabón, chile, aceites, merceria, especies, peines, zapatos, ropa, medias, cuchillos, cuerdas, dulces y aceitunas. ${ }^{77}$

Juan de Sierra Uruñela tenía tres tiendas en el real de minas de Bolaños y, a través de ellas, salían al mercado gran parte de las mercancías de su almacén en la ciudad de México. ${ }^{78}$

Las listas de remisiones incluyen la mayor parte de sitios del reino, Guadalajara, Guanajuato, Tepic, Río Verde, etcétera, es decir, no únicamente los reales de minas.

La mayoría de los comerciantes al menudeo locales en toda la Nueva España dependían de los comerciantes de la ciudad de México para obte. ner sus mercancias:

[...] Estos tenderos no podían generar el volumen de comercio ni la liquidez necesaria para comprar directamente de ultramar. Aun comerciando con sus proveedores de la capital, raramente eran capaces de pagar en efectivo sus pedidos. En realidad, era esta dependencia del crédito lo que ligaba a los tenderos provinciales con las principales casas mercantiles de la ciudad de México $[\ldots]^{79}$

${ }^{76}$ AGl, Alcabalas de la ciudad de México, caja 2, f. suelta. Estos datos son para los años 1787 y 1788.

${ }_{77}$ AGl, Alcabalas de la ciudad de México, caja 2, f. suelta, 1787.

78 Brading, "Minería", 1969, p. 325.

79 Kicza, Empresarios, 1986, p. 98 concluye: 


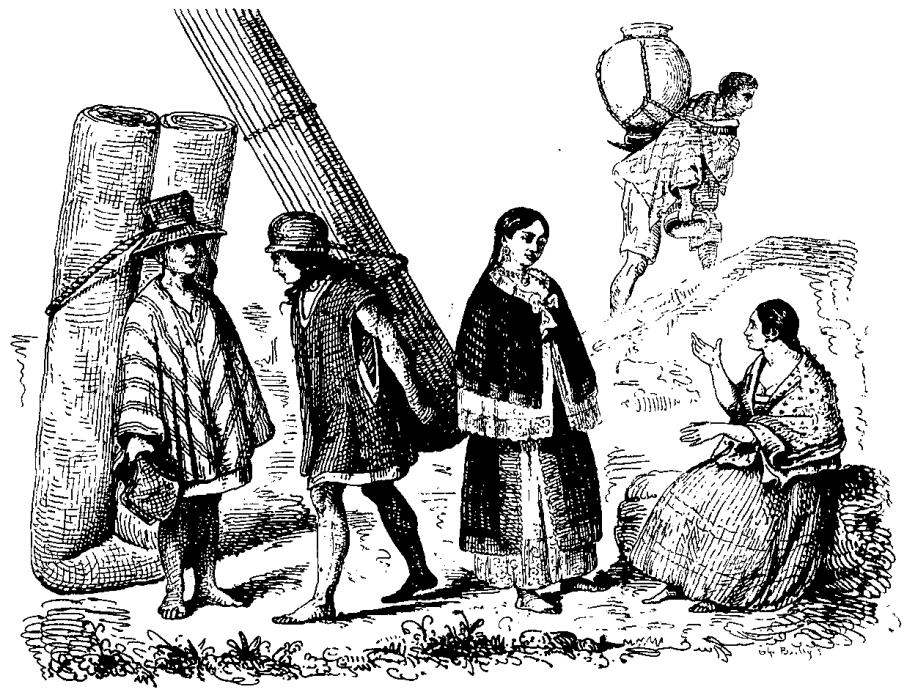

Es así como a traves de cuentas por correspondencia y del sistema de crédito a través de libranzas, los mercaderes de la capital ejercían su predominio sobre el comercio provincial. ${ }^{80}$

... el pequeño comerciante situado en un centro mercantil regional se veía forzado, por lo limitado de sus recursos y de su mercado, a un comercio al menudeo que dependía de la apertura de crédito a sus clientes y, con frecuencia, a la aceptación de mercancías en lugar del pago en efectivo. Esta dependencia endémica en el crédito y en las transacciones de trueque, cuando se combinaba con la escala relativamente pequeña de sus operaciones, colocaba al tendero en una situación de inestabilidad inherente.

${ }^{80}$ Estudios monográficos de ciudades coloniales confirman esta hegemonía comercial de la capital. Véanse para Querétaro, Super, Vida, 1986, pp. 108-133; para Chihuahua, Hadley, Mineria, 1979, pp. 114-129, entre otros. Sobre los
Como lo han demostrado los estudios de Christiane Borchart y de John E. Kicza, los comerciantes de la ciudad de México mantuvieron un dominio comercial sobre los mercados de los centros urbanos de la mayor parte del país, llegando en ocasiones a involucrarse de una manera directa en la producción de ciertos artículos para los mercados interregionales. ${ }^{81} \mathrm{~A}$ lo largo de los caminos reales tendieron una red de tiendas y almacenes para vender directamente en los mercados de

mecanismos de crédito a través de libranzas de pago utilizados preferentemente por los almaceneros de la capital para hacer frente a la escasez de circulante, Pérez Herrero, Plata, 1988, pp. 156-230.

${ }_{81}$ Kicza, Empresarios, 1986, p. 94. 
provincia. Sus casas mercantiles fungieron como proveedoras casi absolutas de los reales mineros, y su poder para operar otorgando crédito a los múltiples clientes contribuyó a desarmar la posible competencia de las firmas comerciales de provincia, siempre con menores recursos.

El comercio entre Durango y la ciudad de México reflejaba fielmente esta situación:

[...] se empleaban miles de mulas en el comercio entre Durango y la capital. Llegaban cargadas con barras de plata, con cueros, sebo, granos, un poco de vino, chile $y$ algunas veces trigo; $y$ regresaban con artículos para las minas (azogue, acero y fierro), aguardiente y manufacturas, tanto extranjeras como domésticas $[\ldots]^{82}$

Varios factores fueron decisivos en esta primacía comercial. Entre los más importantes se encuentra la ubicación de la capital como único núcleo de la red de transporte colonial; ${ }^{83}$ su capacidad financiera para operar a crédito a través de libranzas y otros medios de pago; ${ }^{84}$ sus estrechos vínculos con la producción minera y con ello su acceso directo a la liquidez necesaria para efectuar sus compras en las mejores condiciones; ${ }^{85}$ los nexos y alian-

82 Ward, México, 1981, p. 278.

83 Pocos estudios de historia económica han reparado en este factor locacional que en el siglo xxx llegó a convertirse en uno de los más serios obstáculos para el desarrollo económico de México: el carácter sumamente deficiente y centralizado del transporte en México. Coatsworth, "Obstacles", 1978, p. 91.

84 Pérez Herrero, Plata, 1988, pp. 195 y ss.

85 Sobre los distintos medios que utilizaban zas que a nivel incluso familiar tenian los comerciantes de la capital con sus proveedores de España y Filipinas ${ }^{86}$ y, finalmente, su capacidad organizativa para transformar y reelaborar gran parte de las materias primas en las pequeñas industrias artesanales, fabriles y textiles de la capital.

Si bien el comportamiento económico de los grandes comerciantes de México no era estrictamente moderno, vale decir que sus estrategias familiares eran adecuadas:

en una economía de mercados fundamentalmente desarticulados, en los cuales la información sobre precios, oferta, demanda y otras cosas, era suministrada no tanto por las operaciones de los mecanismos de mercado como por las redes de información de boca a boca. En tal circunstancia los costos de información era altos y la velocidad baja, por to que el parentesco funcionaba como un canal importante y aseguraba la confiabilidad al mismo tiempo. $^{87}$

los comerciantes para tener acceso preferencial a la plata de las minas: $a$ ) instalar tiendas en los reales de minas; $b$ ) realizar acuerdos directos de abasto y suministro con los mineros y $c$ ) realizar inversiones directas en las companías de minas, véanse Kicza, Empresarios, 1986, pp. 102-107 y Brading, Mineros, 1975, caps. I y II.

86 Véase por ejemplo el caso de Francisco Yraeta en Torales Pacheco, Compañia, 1985, vol. 1, pp. 19-74. O bien, el de la familia David en Yuste, Comercio, 1984.

87 Van Young, "Siglo", 1988, p. 221; Coatsworth, Origenes, 1990 , p. 98 seffala: "Ia naturaleza intervencionista y continuamente arbitraria del medio institucional obligaba a cada empresa, fuese urbana o rural, a operar en forma sumamente politizada, aprovechando redes de parentesco, influencia política y prestigio familiar para ganar acceso privilegiado a créditos 
Por otra parte, desde mediados del siglo XVII, el comportamiento de los mercaderes de México no era sustancialmente distinto del desempeñado por los comerciantes de Boston, Sao Paulo, Buenos Aires o Lisboa, para el mismo periodo. ${ }^{88}$

Una valiosa fuente de crédito para las fuertes inversiones que requería este tipo de comercio, la hallaban los mercaderes en las cofradías elitistas fundadas por ellos, según la provincia española a la que pertenecieran. La cofradía de Aránzazu otorgó empréstitos y crédito a sus miembros mineros y mercaderes, todos descendientes de vascos; el Santo Cristo de Burgos hizo lo propio con los montañeses; exactamente el mismo caso se dio con los mercaderes portugueses y españoles de Sao Paulo y Buenos Aires, respectivamente, en el siglo XVIII, con la cofradía de la Santa Casa da Misericordia. 89

Sus métodos y procedimientos no

subsidiados, aplicar diversas estratagemas para reclutar mano de obra, cobrar deudas o aplicar contratos, evadir impuestos o la acción de los tribunales, o defender o afirmar los derechos sobre la tierra. El éxito o el fracaso -concluye el autor- en el terreno económico dependía siempre de las relaciones del productor con las autoridades políticas, ya con funcionarios locales para arreglar asuntos inmediatos, ya con el gobierno central de la colonia, cuando las condiciones lo exigían."

88 Hoberman y Socolow, Cities, 1986, p. 494; Kuznesof, "Role", 1980, p. 583; Socolow, Merchants, 1978; Lugar, "Marchants", 1986, pp. 63-67.

89 Kuznesof, "Role", 1980, señala: "This important public welfare agency was also known to function as a banking institution, loaning money for commercial enterprises." Lugar, "Marchants", 1986 , pp. 67 y ss. siempre iban conforme a las leyes, y en más de una ocasión se valieron de sus influencias para anular y contrarrestrar medidas oficiales tendientes a socavar su poder económico. ${ }^{90}$

Todos los factores arriba mencionados convirtieron a la ciudad de México en el indiscutible centro rector dc la distribución comercial y, en buena medida, de la transformación de la producción nacional.

En el siglo XIX, cuando las fricciones entre el gobierno nacional y los comerciantes españoles trajeron la pérdida del control mercantil por estos últimos, los comerciantes extranjeros que los reemplazaron, americanos, ingleses, alemanes y franceses, decidieron establecerse nuevamente en la ciudad de México para, de ahí " [...] abastecer directamente sin intermediario, a los comerciantes al menudeo del interior $[\ldots] " 91$

Lo mismo había sucedido a prin-

90 Stein, "Bureaucracy", 1981, pp. 2-3 enfoca la manera en que los comerciantes enfrentaron exitosamente el intento borbónico por desaparecer los repartimentos de mercancías, esto es la forzosa distribución y compra de bienes a altos precios en las alcaldías indígenas. Los comerciantes pagaban las fianzas de los alcaldes mayores a fin de que éstos consolidaran un mercado cautivo en su jurisdicción, donde sólo las mercancías de los fiadores pudieran ser vendidas a precios por lo general mayores de los del mercado. Véase también en Lugar, "Marchants", 1986 , p. 61 .

91 Ward, México, 1981, p. 281. El ministro ingles no estaba de acuerdo con la decisión de los comerciantes extranjeros: "no puedo menos de pensar -argüía- que, al intentar abastecer desde un solo punto (por más céntrico que éste sea) a un país de tan vasta extensión como México, repiten, de hecho, el error cometido por los españoles [...]" 
cipios del siglo xvil cuando los comerciantes vascos y montañeses reemplazaron a los andaluces y portugueses en el control del tráfico novohispano, pues los mercaderes del País Vasco y Cantabria decidieron localizar sus firmas empresariales en la ciudad de México. ${ }^{92}$

Hacia finales del siglo XvII, la economía de la Nueva España estaba fincada, casi exclusivamente, en las actividades agrícolas y, en menor grado, las mineras. La suma de ambas representaba cerca del $90 \%$ de la producción total. En este mundo fisiocrático, las ciudades fungían como centros comerciales para atender los requerimientos del sector primario.

La ciudad de México, como hemos visto, aprovechando las ventajas locacionales, económicas y políticas, se constituyó en el núcleo principal de estas actividades de intercambio, inaugurando así una economía mercantil que, a la postre, serviría como base para generar y acrecentar su abrumadora hegemonia sobre el resto de las ciudades mexicanas.

\section{BiBLIOgRAFÍA}

-Altman, I. y J. Lockhart, Provinces of early Mexico variants of spantsh american re-

92 Hoberman, Cities, 1986, p. 496, encontró que a mediados del siglo xuI la mayor parte de comerciantes del Consulado de México provenían del sur de España, en tanto que, en la siguiente centuria, el tribunal de mercaderes de México quedó en manos de vascos y montaheses; con la excepción de Pedro Romero de Terreros, ningún comerciante a gran escala del Consulado provenía de la España meridional. gional evolution, Universidad de California, Los Ángeles, 1976.

-Arcila Farías, Eduardo, Comercio entre México y Venezuela en los siglos XV y XVI, Instituto Mexicano de Comercio Exterior, México, 1975.

-Bahena, Margarita, "La transportación de carga en el comercio de la Nueva España: la arriería (1789-1810)", tesis de licenciatura en historia, Universidad Iberoamericana, México, 1985.

-Barrett, Ward, "Morelos and its sugar industry in late eighteenth-century", en I. Altman y J. Lockhart, Provinces, 1976.

-Borchart de Moreno, Christiana R., Los mercaderes y el capitalismo en la ciudad de México (1759-1778), FCE, México, 1984.

-Brading, David A., "Comments on "The economic cycle in bourbon central Mexico: A critique of the Recaudacion del diezmo liquido en pesos', by Ouweneel and Blijleveld", Hispanic American Historical Review, vol. LXXX, núm. 3, 1989. , "La minería de plata en el siglo XVII: el caso de Bolaños", Historia Mexicana, vol. xvIII, núm. 3(71), eneromarzo de 1969.

\section{, Mineros $y$ comerciantes en} el México borbónico (1763-1810), FCE, México, 1975.

-Bronner, Fred, "Urban society in colonial Spanish America: research trends", Latin American Research Review, vol. XXI, núm. 1, 1986.

-Busto, Emiliano, Estadística de la Re. pública Mexicana, 3 vols., Imp. de Ignacio Cumplido, México, 1880.

-Coatsworth, John H., "Comments on 'The economic cycle in bourbon central Mexico: A critique of the Recaudacion del diezmo liquido en pesos', by Ouweneel and Blijleveld", Hispanic American Historical Review, vol. LXIX, núm. 3, 1989. , "Obstacles to economic growth in nineteenth-century Mexico", Hispanic American Historical Review, vol. LXXXIII, núm. 1, febrero de 1978. 
Los origenes del atraso. Nueve ensayos de bistoria económica de México en los siglos XVII y $\mathrm{x} x$, Alianza Editorial Mexicana, México, 1990.

-Florescano, Enrique, Descripciones económicas generales de Nueva España, 1784-1817, Instituto Nacional de Antropología e Historia, México, 1973.

-Florescano, E. y Fernando Castillo, Controversia sobre la libertad de comercio en Nueva España, (1776-1818), 2 vols., Instituto Mexicano de Comercio Exterior, México, 1975.

-Fonseca, Fabián de y Carlos de Urrutia, Historia General de la Real de Hacienda, Imprenta de Vicente García Torres, México, 1849-1853.

Garavaglia, Juan Carlos, y Juan Carlos Grosso, Las alcabalas novohispanas (1776-1821), Archivo General de la Nación/Banca Cremi, México, 1987.

_. - "Marchands, hacendados et paysans a Tepeaca. Un marché local mexicain a la fin du xuıle siècle", Annales. Economies, Sociétés, Civilisations, núm.3, mayo-junio de 1989.

-Gamer, Richard L., "Price tense in nineteenth century Mexico", Hispanic American Historical Review, vol. LXV, núm. 2, 1985.

-Hadley, Phillip L., Minería y sociedad en el centro minero de Santa Eulalia, Chibuabua (1709-1750), FCE, México, 1979.

-Hamnett, Brian R., "Dye production, food supply, and the laboring population of Oaxaca, 1750-1820", Hispanic Amertcan Historical Review, vol, LI, núm. 1, febrero 1971.

-Haring, Clarence H., Comercio y navegación entre España $y$ las Indias en la época de los Habsbungos, FCE, México, 1979.

-Hassig, Ross, Trade, tribute and transportation. The sixteenth-century political economy of the valley of Mexico, University of Oklahoma Press, Norman, 1985.
-Hoberman, Louisa, y Susan M. Socolow (comps.), Cities and soctety in colonial Latin America, University of New Mexico Press, Albuquerque, 1986.

-Kicza, John E., Empresarios coloniales. Familias $y$ negocios en la ciudad de México durante los Borbones, FCE, México, 1986.

-Kuznezof, Elizabeth A., "The role of the marchands in the economic development of Sao Paulo, 1765-1850", Hispanic American Historical Review, vol, LX, núm. 4, 1980.

-Lugar, Katherine, "Marchants", en L. Hoberman, y S. Socolow (comps.), Cities, 1986.

-Martin, Cheryl E., Rural soctety in colonial Morelos, University of New Mexico Press, Albuquerque, 1985.

-Ortiz Hernán, Sergio, "Caminos y transportes en México a fines de la colonia y principios de la independencia", tesis de licenciatura en economía, Universidad Nacional Autónoma de México, México, 1970.

-Ouweneel, A. y Bijleveld C., "The economic cycle in bourbon central Mexico: $A$ critique of the Recaudacion del diezmo liquido en pesos," Hispanic American Historical Review, vol. LXIX, núm. 3, 1989.

-Ouweneel, Arij y Ma. Cristina Torales Pacheco (comps.), Empresarios, indios y estado; perfil de la economía mexicana (siglo xvIII), Centro de Estudios y Documentación Latinoamericanos, Amsterdam, 1988.

-Pérez Herrero, Pedro, Plata y libranzas. La articulación comercial en el México borbónico, El Colegio de México, México, 1988.

-Piñero, Pedro, "The cacao economy of the eighteenth-century province of Caracas and the spanish cacao market", Hispanic American Historical Review, vol. LXVII, núm. 1, 1988.

-Rees, Peter, "Route inertia and route competition: an historical geography of transportation between Mexico city and 
Veracruz", tesis doctoral, Universidad de California, Berkeley, 1971.

Transportes y comercio entre México y Veracruz, 1519.1910, Secretaría de Educación Pública, México, 1976 (Sepsetentas, 304).

-Ringrose, David R., "Carting in the hispanic world: an example of divergent development", Hispanic American Historical Review, vol. L, núm. 1, 1970.

-Socolow, Susan M., The merchants of Buenos Aires 1778-1810, Cambridge University Press, Cambridge, 1978.

-Stein, Stanley J., "Bureaucracy and business in the spanish empire, 17591804: failure of a bourbon reform in Mexico and Peru", Hispanic American Historical Review, vol. LX, núm. 1, 1981.

-Super, John C., La vida en Querétaro durante la colonia 1531-1810, FCE, México, 1986.

-Taylor, William B., "Town and country in the valley of Oaxaca, 1750-1812", en $I$. Altman y J. Lockhart, Provinces, 1976.

-Torales Pacheco, María Cristina (coord.), La compañía de comercio de Francisco Ignacio de Yraeta (1767-1797), 2 vols., Instituto Mexicano de Comercio Exterior/Universidad Iberoamericana, México, 1985.

-Van Young, Eric J., "Conflict and solidarity in indian village life: the Guadalajara region in the late colonial period", Hispanic American Historical Review, vol. Xl.lv, núm. 1, 1984.

, "El siglo paradójico", en Arij Ouweneel y Ma. Cristina Torales Pacheco (comps.), Empresarios, 1988.

, "Urban market and hinter-

land: Guadalajara and its region in the eigtheenth century", Hispanic American IItstorical Review, vol. LIX, núm. 4, 1979.

-Ward, George H., México en 1827, FCE, México, 1981.

-Watkins, Alfred J., The practice of urban economics, Sage Publications, Beverly Hills-Londres, 1980.

-Yuste, Carmen, El comercio de La Nueva España con Filipinas 1590-1785, Instituto Nacional de Antropología e Historia, México, 1984. 